\title{
Marine vs. terrestrial environments during Early Triassic deposition on the northeastern margin of the Central European Basin - a multidisciplinary study on the Middle Buntsandstein of the Bartoszyce IG 1 borehole, NE Poland
}

\author{
Anna BECKER ${ }^{1, *}$, Anna FIJAŁKOWSKA-MADER ${ }^{2}$ and Marek JASIONOWSKI ${ }^{1}$ \\ 1 Polish Geological Institute - National Research Institute, Rakowiecka 4, 00-975 Warszawa, Poland \\ 2 Polish Geological Institute - National Research Institute, Holy Cross Mts. Branch, Zgoda 21, 25-953 Kielce, Poland
}

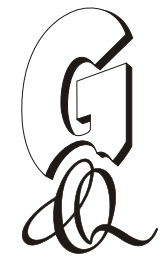
Becker, A., Fijałkowska-Mader, A., Jasionowski, M., 2020. Marine vs. terrestrial environments during Early Triassic deposi-
tion on the northeastern margin of the Central European Basin - a multidisciplinary study on the Middle Buntsandstein of the
Bartoszyce IG 1 borehole, NE Poland. Geological Quarterly, 64 (4): 1023-1047, doi: $10.7306 / g q .1566$

The Middle Buntsandstein Subgroup of the Lower Triassic of north-eastern Poland has been investigated in the context of possible marine ingressions into the Central European Basin. To better constrain these, palynofacies analysis and mineralogical analysis of mudstones were undertaken on samples taken from the Lidzbark and Malbork formations penetrated by the Bartoszyce IG 1 borehole, serving as stratotype section of both lithostratigraphic units. Microfacies and geochemical analyses, including $\mathrm{C}$ and $\mathrm{O}$ isotope analysis, were conducted additionally on oolitic limestones of the basal Lidzbark Formation (the lowermost Middle Buntsandstein), and the boron content was measured on all mudstone samples. Seven palynofacies types are distinguished: types 1 to 3 within the Malbork Formation and types 4 to 7 within the Lidzbark Formation. Types 1 and 2 originated on a floodplain, type 3 probably in a deltaic or barrier setting, and types 4 and 5 in a brackish lagoon or a more open basin, possibly of marine origin. Palynofacies type 6 reflects long transport and reworking, whereas palynofacies type 7 is interpreted as formed due to pedogenic processes. Clay minerals and quartz, accompanied by feldspars, calcite and dolomite are the main components of the mudstones investigated. The clay mineral association consists of illite or a mixture of illite and smectite, and chlorite. The Lidzbark Formation and the lowermost part of the Malbork Formation show less variability in mineralogical composition than the upper part of the Malbork Formation. Smectite admixtures were detected only in the upper part of the Malbork Formation (the uppermost Middle Buntsandstein). The boron content, achieved after aqua regia digestion, ranges from 70 to $121 \mathrm{mg} / \mathrm{kg}(96 \mathrm{mg} / \mathrm{kg}$ at average), oscillating generally around $90 \mathrm{mg} / \mathrm{kg}$. A higher boron content, bound in silicate structure, is associated with the upper part of the Malbork Formation. All major mineralogical and geochemical changes coincide more or less with the transition from the supposed marine to the terrestrial environmental realm, interpreted from lithological and sedimentological observations within the lowermost part of the Malbork Formation. However, diagenetic alteration of the clay minerals, and of the boron content, could not be ruled out. The oolitic limestones, mainly grainstones, contain admixtures of quartz grains and rare bioclasts, the ooids nuclei being peloids or unrecognizable. The carbonates are almost exclusively composed of low-Mg calcite. A high content of $\mathrm{Mg}$ and the presence of small amounts of dolomite suggest that the ooids were primarily composed of high-Mg calcite and are comparable with similar Early Triassic deposits in Tethyan settings. The $\delta^{13} \mathrm{C}$ values range from -2 to $+1 \%$ VPDB, fitting well with the known ranges of Lower Triassic marine carbonates. An observed $\delta^{13} \mathrm{C}$ depletion towards the top of the oolite-bearing part of the section may reflect a local shallowing trend that led to overall salinity decrease. A possible connection with the one of the global oceanic geochemical episodes has to be tested further. The results obtained suggest a marine origin of the lower Middle Buntsandstein deposits studied and document a terrestrial origin for the upper Malbork Formation.

Key words: Lower Triassic, northeastern Poland, palynofacies, clay mineralogy, oolite microfacies, isotope geochemistry.

\section{INTRODUCTION}

The sedimentary environments of the Lower Triassic deposits of the epicontinental Central Europen Basin are still poorly understood. Interpretation of the deposits of the Lower and Middle Buntsandstein as either terrestrial (e.g., a playa lake

\footnotetext{
* Corresponding author, e-mail: anna.becker@pgi.gov.pl
}

Received: March 27, 2020; accepted September 30, 2020; first published online: November 23, 2020 sensu Paul, 1982, 1999a and Briere, 2000) or marine (an epicontinental lagoon) remains topic of scientific discussion. On the one hand, a non-marine origin seems to be well-documented. Marine macrofauna is almost lacking, unlike the fresh to brackish water fauna (conchostracan), present in large numbers. Sedimentary structures, documenting emersion (e.g., desiccation cracks), had been widely described. On the other hand, these deposits contain foraminifers and acritarchs as well as glaucony (sensu Odin and Matter, 1981) in oolitic limestones, which traditionally are regarded as characteristic of marine facies (see e.g., summary by Becker, 2005, 2007). The strongest marine influences or even open marine conditions are postulated especially for the lower part of the Middle Buntsandstein succession of western Poland (see e.g., 


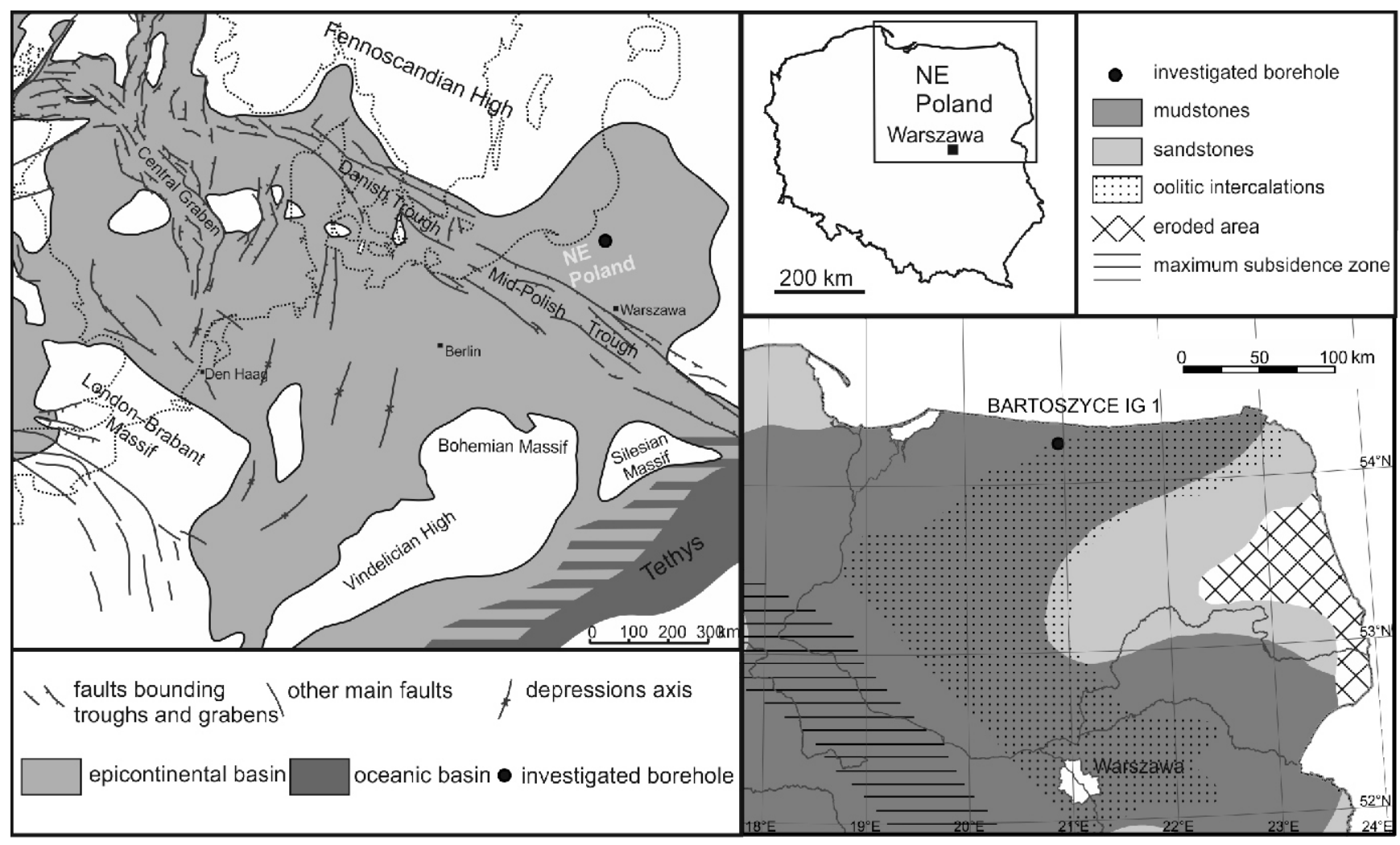

Fig. 1. Palaeogeography of the Central European Basin in the Early Triassic with its main tectonic structures (after Ziegler, 1990, modified), locality of area under study, and of the borehole investigated on the background of Middle Buntsandstein facies distribution in NE Poland (after Szyperko-Teller, 1997b, modified)

Fuglewicz, 1973; Peryt, 1975; Szyperko-Teller, 1997b; Becker, 2005, 2014; Feldman-Olszewska, 2014; Szulc, 2019), as has also been described from northern Germany (Heunisch and Röhling, 2016). So far the region of north-eastern Poland has been relatively poorly investigated in terms of the depositional environments and palaeogeography of this interval. Fuglewicz (1973) interpreted the Buntsandstein in Poland, based on lithology and megaspores, as deposited in an epeiric basin, which was at first connected to the north-west with the Boreal Sea and later to the south-west with the Tethys. A similar interpretation based on facies analysis and occurrence of foraminifers was proposed by Szulc (in Beutler and Szulc, 1999, 2019) following the results of Pieńkowski (1991) and of detailed microfacies analysis (Szulc, 2019). Szulc et al. (2015) and Szulc (2019) dated the closure of the northern gateways and the simultaneous opening of the southern seaway (East Carpathian Gate) to the later Induan (Dienerian). Palaeogeographic interpretations, based on lithological and basic palaeontological observations, were proposed by Szyperko-Śliwczyńska (1979) and by Szyperko-Teller (1997b). Szyperko-Śliwczyńska (1979) inferred that the Lower and Middle Buntsandstein were deposited in a brackish basin with brief marine influences from an undetermined direction. Szyperko-Teller (1997b) deduced a marine ingression from the Boreal Sea at the beginning of Lower Buntsandstein deposition and from the "Alpine sea" at the beginning of Middle Buntsandstein deposition. Pieńkowski (1991) linked the marine ingressions to a global transgression at the beginning of the Triassic. Bachmann et al. (2010) described the Lower and Middle Buntsandstein as a continental succession with subordinate marine influence in the eastern and central parts of the Central European Basin. In the German and other West European literature there prevails an interpretation of a lacustrine origin of oolitic and stromatolitic limestones of the Buntsandstein (Paul, 1999b; Paul and Peryt, 2000; Voigt and Gaupp, 2000; Korte and Kozur, 2005; Palermo et al., 2008; Paul et al., 2011). Recently, Szulc (2019) provided convincing arguments for marine incursions of varied magnitude, based on his finds of a rich assemblage of marine invertebrates (gastropods, microconchids and sponges) within the lower Middle Buntsandstein of Western Poland. Marine ingressions were often postulated basing on phytoplankton occurrence or even dominance within the palynomorph spectra of the Buntsandstein of the Polish and German basins (e.g., Schön, 1967; Orłowska-Zwolińska, 1977, 1984, 1985; Reitz, 1985; Fijałkowska-Mader, 1999; Heunisch and Röhling, 2016). Despite these discussions in the literature, though, detailed, interdisciplinary investigations on this topic are still rare or absent. Most published contributions discuss the overall development of the Central European Basin or its component Polish or German basins without going into detail. Likewise, there are few interpretations based on research that integrates a broad spectrum of methods. In this paper we demonstrate an integrated approach comprising palynofacies analysis, clay mineralogy, boron content, and oolitic microfacies, including isotope geochemistry, to the interpretation of the depositional environment of the Middle Buntsandstein deposits of the Bartoszyce IG 1 borehole in north-eastern Poland (Fig. 1), initially investigated over forty years ago (Szyperko-Śliwczyńska, 1974, 1979; Nowicka, 1974a, b). This paper tests current generalized interpretations of epicontinental Early Triassic deposition using detailed methodologically diverse studies of a fully cored section. Macroscopic observation of lithology and of main sedimentary structures preceded the laboratory studies. Our research was conducted within the scope of a comprehensive project of the 
State Geological Survey of Poland, designed to protect the stratotype sections of borehole cores and to provide complementary investigations of them. Core intervals of Bartoszyce IG 1 borehole serve as stratotypes for lithostratigraphic units of the Lidzbark and Malbork formations of the Middle Buntsandstein of northeastern Poland (Szyperko-Śliwczyńska, 1979).

\section{GEOLOGICAL SETTING}

\section{REGIONAL AND STRATIGRAPHIC FRAMEWORK}

During the Early Triassic, the area of north-eastern Poland formed the easternmost margin of the epicratonic Central European Basin (Fig. 1), in which fluvial, as well as playa lake (sensu Paul, 1999a) to marginal marine deposits were laid down (e.g. Bachmann et al., 2010). The subtropical monsoon climate conditions, characterized in general by strong seasonality, were predominantly dry to semi-dry (e.g., Kutzbach and Gallimore, 1989; Van der Zwan and Spaak, 1992; Parrish, 1993; Fijałkowska-Mader, 1999, 2015). The region investigated was located north-east of the local depocentre of the Polish part of the basin, formed by the Mid-Polish Trough (Fig. 1), where subsidence was noticeably reduced, due to the stiff Precambrian platform substrate. The source area of the clastic sediments was the Fennoscandian High to the north and the Belorussian High to the east (Szyperko-Teller and Moryc, 1988; Szyperko-Teller, 1997b). In the region discussed, muddy and sandy red-brownish deposits with grey oolitic intercalations are typical of the lower and middle part of the Buntsandstein succession, whereas reddish and grey sandy deposits dominate its upper part (Figs. 1 and 2). The thickness of the whole succession does not exceed $400 \mathrm{~m}$ (Szyperko-Teller and Moryc, 1988; Bachmann et al., 2010).

The Buntsandstein Group of north-eastern Poland is composed of the Baltic, Lidzbark, Malbork and Elbląg formations (Szyperko-Śliwczyńska, 1979; Szyperko-Teller and Moryc, 1988; Szyperko-Teller, 1997a; Fig. 2). The Baltic Formation is the only lithostratigraphic unit distinguished in the Lower Buntsandstein. The Middle Buntsandstein consists of the Lidzbark and Malbork formations, whereas the Upper Buntsandstein includes mainly the Elbląg Formation. In parts of the region the Upper Buntsandstein Subgroup encompasses additionally a carbonate-clastic unit, lying above the Elblag Formation or composing its lateral equivalent (Szyperko-Teller, 1997a). The Buntsandstein succession is dated as Lower Triassic to Middle Triassic in its uppermost part (OrłowskaZwolińska, 1984; Marcinkiewicz, 1992; Senkowiczowa, 1997; Marcinkiewicz et al., 2014). This paper is focused on the Middle Buntsandstein Subgroup of the Bartoszyce IG 1 borehole. The recent chronostratigraphic studies of Becker et al. (2020) have shown that the section investigated lies within the Densoisporites nejburgii Subzone of Orłowska-Zwolińska (1984) and stretches over the Tbr5 reversed zone and undivided Tbn6-Tbn7 normal zones defined in the magnetostratigraphic scheme of Nawrocki (1997), which suggests an Olenekian age (see e.g., Hounslow and Muttoni, 2010; Nowak et al., 2018). The Lidzbark and Malbork formations correlate with the Pomerania and Połczyn formations of western Poland and the Volpriehausen, Detfurth and Hardegsen formations of north-western Germany (Szyperko-Teller, 1997a; Becker, 2005; Becker et al., 2008; Bachmann et al., 2010; Fig. 3).

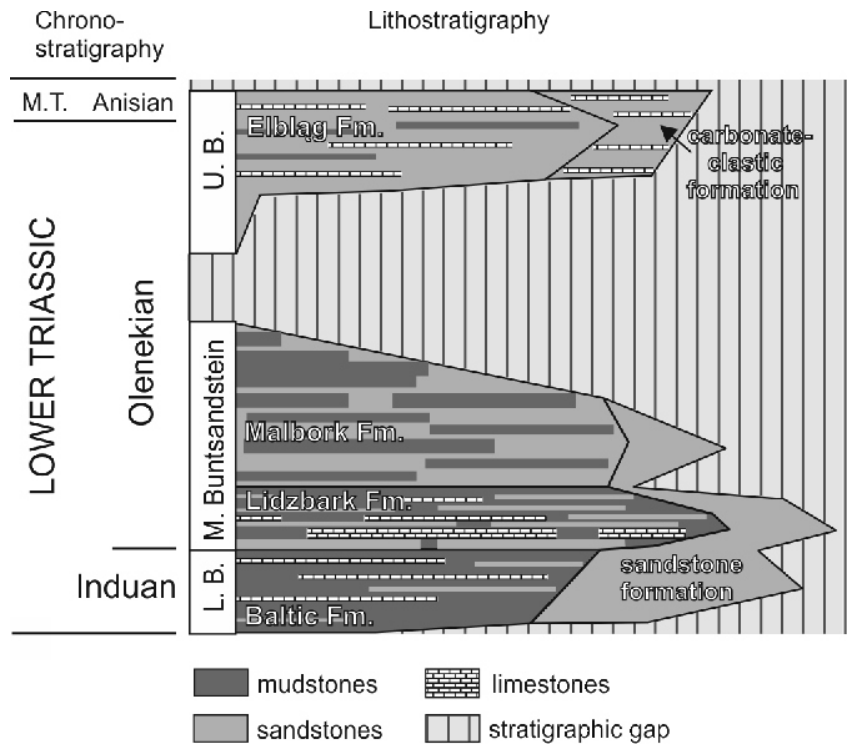

Fig. 2. Stratigraphical and lithological scheme of the Lower Triassic in NE Poland

(after Becker et al., 2008 and Marcinkiewicz et al., 2014)

M.T. - Middle Triassic; L. B., M., U. B. - Lower, Middle, Upper Buntsandstein, respectively

LITHOLOGICAL AND SEDIMENTOLOGICAL BACKGROUND

LIDZBARK FORMATION

The Lidzbark Formation, recognized by Szyperko-Śliwczyńska (1979) in the Bartoszyce IG 1 borehole in the depth interval of 987.9-1049.2 $\mathrm{m}$ can be subdivided into three lithological units (Fig. 4). The lowermost unit (depth 1045.6-1049.2 m) consists of horizontally or cross-laminated sandy mudstones, partly brecciated, weakly horizontally laminated mudstones with subordinate oolitic limestone lenses and fine-grained muddy sandstones with flaser to wavy or horizontal lamination (Fig. 5A). Red to red-brown colours at the base turn gradually into grey colours in the uppermost part of the succession. The overlying unit (depth 1033.8-1045.6 m; Fig. 4) consists of weakly horizontally laminated or massive clay- and mudstones, with individual lenses of ooids or cracks filled with ooids, and characterized by reddish-brown to violet or grey colours. There are intercalated oolitic limestones, partly sandy or argillaceous. The limestones have a more or less strong claystone content, show flaser lamination or contain clay intraclasts locally accompanied by an erosional surface. Hummocky cross-lamination occurs rarely in the oolitic layers. The limestones have grey to reddish-brown colours (Fig. 5B). The third lithological unit (depth 987.9-1033.8 m; Fig. 4), builds the uppermost part of the formation, which is dominated by calcareous claystones. These are horizontally or lenticular laminated (partly weakly) or massive, with very thin laminae or lenses of argillaceous limestone or marl and thin intercalations of oolitic limestone (Fig. 5C-E). Small cracks filled with ooids or mudstone occur at some levels. The claystones vary in colour from reddish-brown-violet at the base, through greenish-grey in the middle part of the unit, to reddish-brown at the top. Some 


\begin{tabular}{|c|c|c|c|c|c|c|}
\hline \begin{tabular}{|c|} 
Chrono- \\
strati- \\
graphy
\end{tabular} & \multicolumn{3}{|r|}{ NW Germany } & \multicolumn{2}{|r|}{ W Poland } & NE Poland \\
\hline 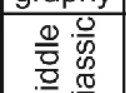 & \multicolumn{3}{|r|}{ MUSCHELKALK } & \multicolumn{2}{|r|}{ MUSCHELKALK } & MUSCHELKALK \\
\hline \multirow{4}{*}{ 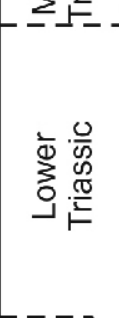 } & \multirow{4}{*}{ 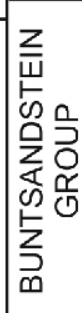 } & Upper & \begin{tabular}{|c|} 
RÖT FM. \\
$\sim \sim$ SOLLING FM.
\end{tabular} & ב & BARWICE FM. $\quad$ ROTFM. & $\mathrm{CCF} \leq$ ELBLĄG FM. \\
\hline & & \multirow{2}{*}{$\frac{\frac{0}{\bar{g}}}{\frac{\partial}{2}}$} & \multirow{2}{*}{ VOLPRIEHAUSEN FM. } & \multirow{2}{*}{ 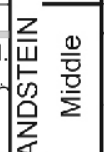 } & POKCZYN FM. & MALBORK FM. \\
\hline & & & & & $\widetilde{\text { POMERANIA FM. }}$ & LIDZBARK FM. \\
\hline & & 产 & CALVÖRDE FM. & 勇 & BALTIC FM. & BALTIC FM. \\
\hline 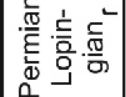 & \multicolumn{3}{|r|}{ ZECHSTEIN } & \multicolumn{2}{|r|}{ ZECHSTEIN } & $\begin{array}{l}\text { ZECHSTEIN/ older than } \\
\text { Zechstein }\end{array}$ \\
\hline
\end{tabular}

Fig. 3. Correlation chart of the Buntsandstein lithostratigraphic units between Germany and Poland encompassing the middle and eastern parts of the Central European Basin (after Bachmann et al., 2010; modified after Senkowiczowa, 1997; Szyperko-Teller, 1997a; Becker, 2005 and Becker et al., 2020)

possible bioturbation structures have been observed in the lower part of the unit. In the uppermost part, mottled laminae and root traces have been detected (Fig. 4F). Fish scales occur sporadically. Styk (1974) reported on the occurrence of an ostracod assemblage and very rare oogonia of charophytes within the deposits of this third lithological unit and on the lack of microfaunal remains in the lower part of the Lidzbark Formation.

The depositional environment of the Lidzbark Formation was generally interpreted by Nowicka (1974a, b) as a shallow basin with increased salinity, with sedimentation taking place below wave base, and the sandstones representing a shallower regime than the fine-grained deposits. Szyperko-Śliwczyńska (1979), Fuglewicz (1980) and Szyperko-Teller (1997b) proposed similar interpretations, but stressed the marine conditions of deposition, which weakened upsection. They postulated that the sandy and oolitic deposits represented higher-energy conditions than the finer grained deposits. SzyperkoŚliwczyńska (1979) and Fuglewicz (1980) postulated additionally increased climatic humidity compared with the time of the Lower Buntsandstein deposition. Szyperko-Teller (1997b) placed the region of the Bartoszyce IG 1 borehole within the transition area between ooidal shoals and the centre of the shallow epicontinental marine basin. Further interpretations can be found on different paleogeographic maps. Iwanow and Kiersnowski (1998) that the lower part of the Middle Buntsandstein in Poland represented a brackish basin (lagoon). Beutler and Szulc (1999) draw a boundary between eroded land and shallow sea in the region of NE Poland in the Induan, but described the Middle Buntsandstein as a fluvial succession. Paul (1982, 1999a) proposed a model of a hydrologically closed epicontinental basin, which gathered river waters from surrounding ephemeral channels and which was seasonally filled with rainwater during the time of Lower and Middle Buntsandstein deposition in the Central European Basin. The region of NE Poland were placed by him in the central part of such a basin. Bachmann et al. (2010) inferred a predominantly alluvial plain environment in the area of NE Poland at the beginning of Middle Buntsandstein deposition, which passed later into a playa margin, though also indicated marine ingressions into the Central European Basin during the deposition of the Middle Buntsandstein. Szulc (2019) interpreted the NE Poland area as a region reached by marine ingressions from the Boreal
Sea during the early Induan, i.e. earlier than the succession in discussion was laid down.

Based on the observed macroscopic features (summarized above and on Fig. 4), the descriptions of Szyperko-Śliwczyńska (1974), Styk (1974) and Nowicka (1974a, b) as well as on the variety of former more general and regional interpretations, the development of the Lidzbark Formation succession of the Bartoszyce IG 1 borehole can be characterized as follows. The vertical variability of the formation reflects the development of a very shallow extensive wave-agitated water body. The lowermost unit was deposited in conditions of relatively strong terrigenous input promoting the formation of sandbody topography, possibly as partly exposed barrier islands. Oolitic limestones document a high energy environment of oolitic bars, with ooids dispersed around the bars in form of ooidal shoals. Wave action is documented by hummocky cross stratification. The uppermost part of the formation, corresponding to the third lithological unit, documents deposition from suspension in the low energy environment of a water body. Calcium carbonate precipitation took place episodically. The decline of lamination and its replacement by a massive structure, the appearance of root traces and the formation of stains in the uppermost part of the succession indicate a flattening of the depositional conditions. Reported of findings of ostracods and charophytes are inconclusive as regards a marine or non-marine setting.

MALBORK FORMATION

The Malbork Formation was defined in the Bartoszyce IG 1 borehole by Szyperko-Śliwczyńska (1979) at the depth interval of 898.0-987.9 m. The formation can be subdivided into four lithologically defined units (Fig. 4). The lowermost unit (depth 972.4-987,9 m; Fig. 4) is built of fine-grained muddy sandstones and sandy mudstones, weakly cemented, and light grey or light brown in colour (Fig. 6A). Sedimentary structures are poorly preserved or lacking. Horizontal lamination, cross-lamination and ripple lamination occur locally. The sandstones show a partly nodular structure, depending on the cementation grade. Very strongly disintegrated plant detritus and root traces occur sporadically, as well as scattered conglomerate laminae, composed of sandstone intraclasts. Sandstones and sandy mudstones are intercalated with calcareous clay- to mudstones. The intercalating fine-grained deposits are weakly 


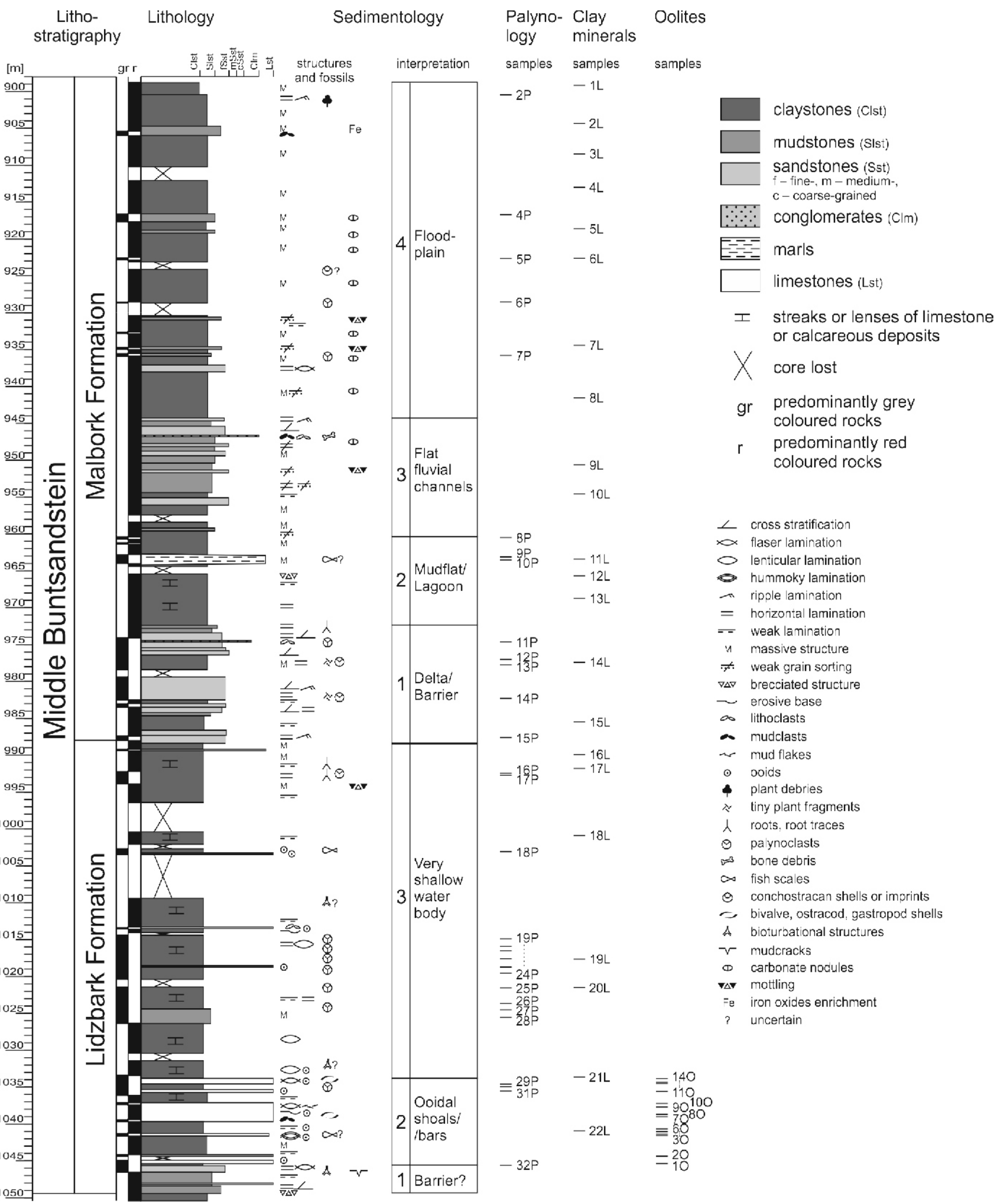

Fig. 4. Lithology and sedimentology of the Middle Buntsandstein section of the Bartoszyce IG 1 borehole with location of the samples investigated

Lithological units described in the text are marked with numbers in the "interpretation" log; lithostratigraphy after Szyperko-Śliwczyńska (1974, 1979); sedimentological interpretation based on the authors' macroscopic observations and on published literature (see text) 

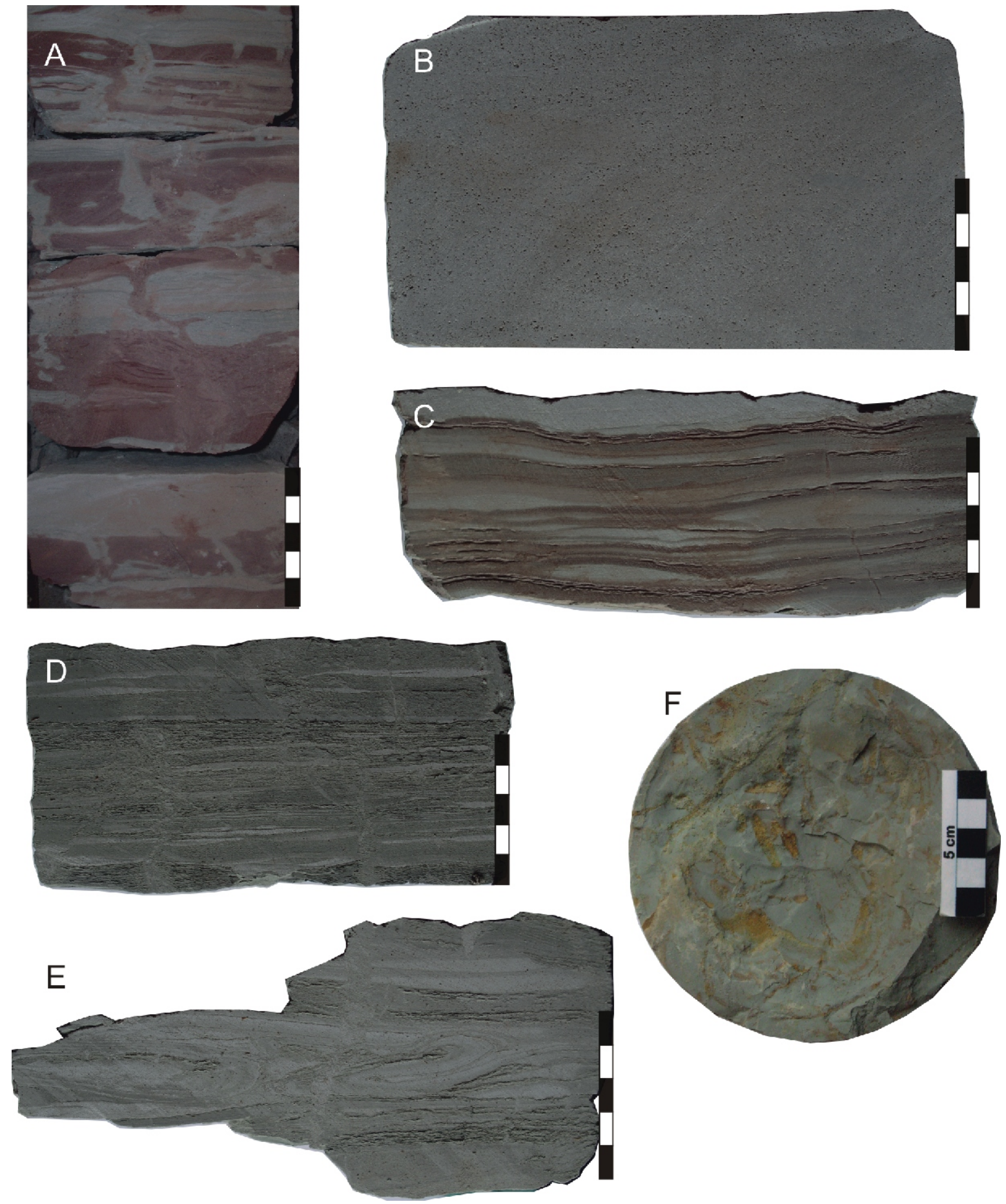

Fig. 5. Examples of Buntsandstein facies of the Bartoszyce IG 1 borehole, Lidzbark Formation

A - wavy stratified muddy sandstone with mudcracks and dewatering structures, depth 1046.45-1046.75 m; B - grey oolitic limestone, depth 1037.40-1037.50 m; C - lenticular laminated grey to red-brown claystone with limestone lenses, depth 1028.77-1028.82 m; D - lenticular laminated grey mudstone, depth 1015.20-1015.27 m; E - soft sediment deformation structures in lenticular laminated grey mudstone, depth 1014.75-1014.80 m; F - root traces on a bedding plane of laminated claystone, depth $992.90 \mathrm{~m}$; scale bar $5 \mathrm{~cm}$ 

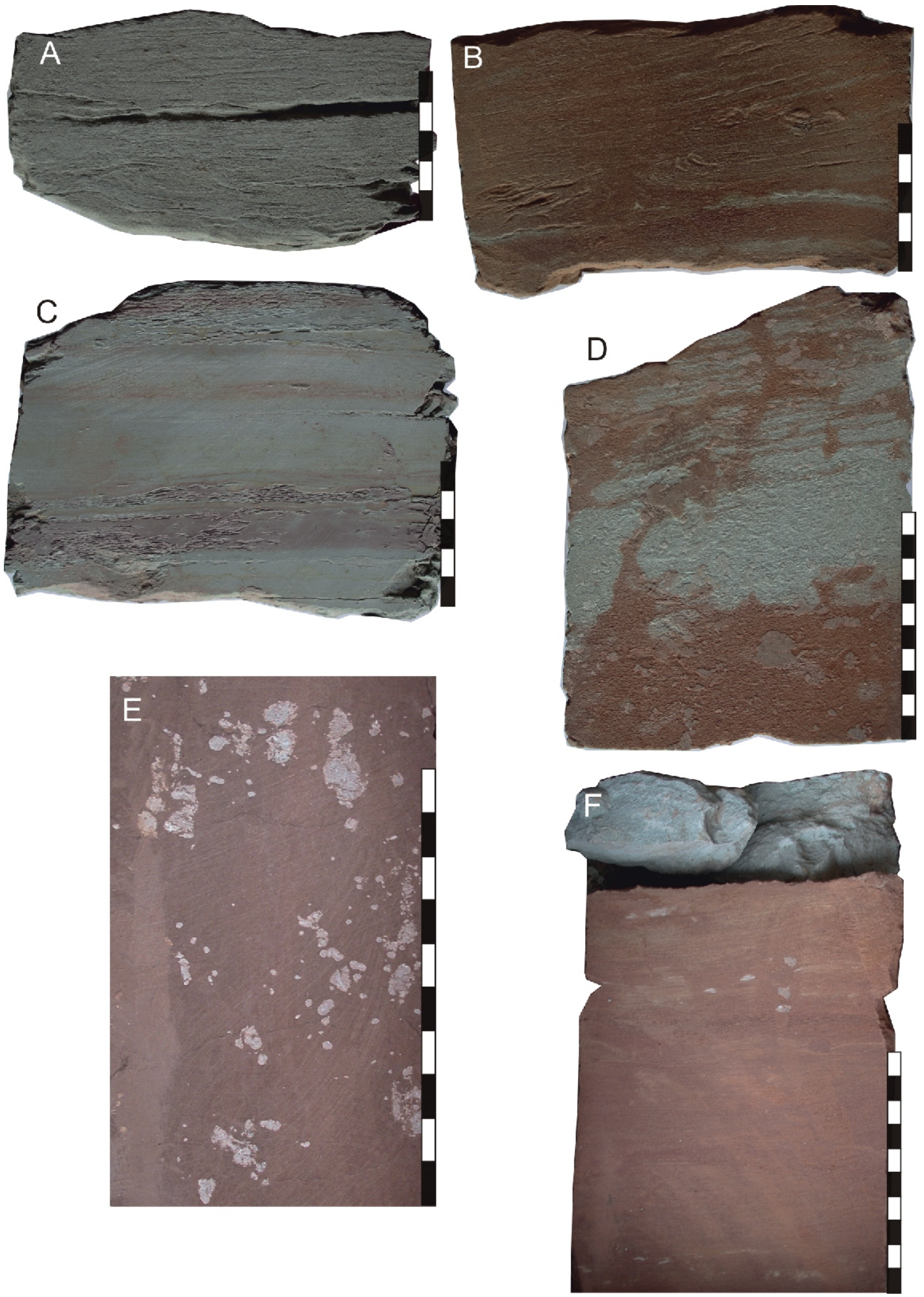

Fig. 6. Examples of Buntsandstein facies of the Bartoszyce IG 1 borehole, Malbork Formation

A - grey cross-laminated muddy sandstone, depth $974.25-974.30 \mathrm{~m}$; B - red-brown cross-laminated muddy sandstone, depth 945.78-945.85 m; C - horizontally laminated mudstone, depth 972.00-972.10 m; D - massive to weakly laminated mudstone with carbonate nodules and colour mottling, depth 930.55-930.70 m; E - massive red-brown mudstone with numerous carbonate nodules, depth 936.00-932.15 m; F - weakly laminated red-brown mudstone with a few carbonate nodules and a thin sandstone intercalation at the top, depth 900.65-900.80 m; A-C: scale bar $5 \mathrm{~cm}$, D-F: scale bar $10 \mathrm{~cm}$ 
horizontally laminated to massive, light green-grey, brown to reddish-brown or variegated. Rare plant detritus also occurs. The deposits of the lowermost lithological unit are arranged in three coarsening-upwards successions, which have a thickness of up to $7 \mathrm{~m}$ (Fig. 4). The overlying unit (depth 960.4-972.4 m; Fig. 4) is built predominantly of calcareous clayey mudstones with reddish-brown to green-grey colours, weakly horizontally laminated to massive with very thin streaks and lenses of marly limestone (Fig. 6C). A single greenish-grey marlstone intercalation occurs in the upper part of the interval. Fish scales occur. Within the third unit (depth 944.4-960.4 m; Fig. 4) sandy clayey mudstones occur, which are poorly sorted or show a disturbed structure, red with greenish-grey cloudy spots. They are interbedded with fine-grained muddy sandstones with massive or disturbed structure (chaotic mixture of mud and sand), mottled in some places. Calcareous nodules occur sporadically within the mudstones, rarely concentrated in distinct horizons. Horizontal, cross- and ripple-lamination was observed within the sandstone layers in the uppermost part of the interval (Fig. 6B). At the base of the thickest sandstone layer, calcareous mudstone clasts, redeposited carbonate nodules and bone fragments form a conglomeratic basal lag. The uppermost lithological unit (depth 898.8-944.4 m; Fig. 4) is dominated by red to greenish-grey, massive or weakly laminated muddy claystones (Fig. 6D-F). Small carbonate nodules are scattered within the deposits, concentrated in some distinct layers. Locally the layers enriched in carbonate nodules show green-grey colours. Layers with ripple or horizontal lamination occur very rarely. The deposits are sporadically intercalated with thin layers of mudstone, sandy mudstone or fine-grained muddy sandstone (Fig. 6F). Their structure is mostly massive or disturbed and mottled. Horizontal and flaser laminations were observed in the sandstones. Claystone intraclasts occur in a single massive sandy mudstone layer enriched in iron oxides. A possible conchostracan imprint and very rare plant detritus were observed. Ostracods were found by Styk (1974) within the first lithological unit, with individual specimens scattered across the remaining part of the profile. Characea, fish scales and teeth were found within the lowermost first unit and uppermost part of the second one (Styk, 1974).

Nowicka (1974a) provided a concise interpretation of the depositional environment of the Malbork Formation of the Bartoszyce IG 1 section. She postulated a strong variability of water depth with possible fluvial deposition of the sandstones in this part of the section. Szyperko-Śliwczyńska (1979), Fuglewicz (1980) and Szyperko-Teller and Moryc (1988) stressed contraction of the basin in their regional interpretations. The basin became a closed inland reservoir according to Fuglewicz (1980) during the deposition of the Malbork Formation. Szyperko-Teller (1997b) postulated additionally a climate change to more arid one, and an early diagenetic origin of carbonate nodules found regularly within reddish structureless mudstones. In the palaeogeographic interpretation of Iwanow and Kiersnowski (1998) an alluvial plain dominated by floodplain deposits spread over NE Poland during the deposition of the upper part of the Middle Buntsandstein. Beutler and Szulc (1999) inferred a dominance of fluvial environments during the Middle Buntsandstein deposition across the whole Central European Basin and Bachmann et al. (2010) interpreted the Malbork Formation as an alluvial plain succession.

Based on own macroscopic observations characterized above and summarized on Figure 4 as well as on the descriptions of Szyperko-Śliwczyńska (1974), Nowicka (1974a) and Styk (1974) and on the former regional interpretations, the following more precise interpretation of the Malbork Formation succession of the Bartoszyce IG 1 borehole can be proposed.
The lowermost, sandy part of the formation, arranged in coarsening-upwards successions, suggests deposition within a weakly developed prograding delta or barrier islands. The overlying clayey-marly part originated from deposition in the calm environment of a very shallow lagoon or mudflat. The subsequent shallowing of the environment let to the development of an ephemeral, immature fluvial system of the uppermost part of the formation, with rare shallow, unstable channels on an extensive floodplain similar to the gilgai floodplain of the Upper Triassic of southern Poland (Jewuła et al., 2019).

\section{MATERIAL AND METHODS}

\section{PALYNOFACIES}

Thirty-one samples from the core interval of 900.41-1045.75 m were examined but only nineteen yielded palynological material (Figs. 4 and 7 ). The rock material was treated according to the method described in OrłowskaZwolińska (1983). All organic matter particles were interpreted in terms of palynofacies analysis. For quantitative analysis 200 palynoclasts were counted per slide. Only in very sparse spectra were all palynoclasts counted.

The definition of Powell et al. (1990) was applied for palynofacies, where palynofacies means "a distinctive assemblage of palynoclasts whose composition reflects a particular sedimentary environment".

Organic matter particles (palynoclasts) that occur in the material investigated were classified according to the Amsterdam Palynological Organic Matter Classification '93 (APOMC) into the following groups: (1) palynomorphs - spores, pollen, freshwater algae, comprising chlorococcalean and other green algae; (2) structured matter (STOM) - wood, cuticles, plant tissues; (3) degraded structural matter (DOM) and 4) unstructured/amorphous matter (AOM). The latter comprises the following particles without structure and/or shape reflecting tissue organization: heterogeneous particles (particles $>1-2 \mu \mathrm{m}$ with well-defined outline), finely dispersed matter (particles $<1-2 \mu \mathrm{m}$ ) and so called "fluffy" matter (translucent, aggregate matter without sharp outlines, probably of planktonic or/and bacterial origin; Batten, 1996). This is not Amorphous Matter sensu Boulter and Riddick (1986), which corresponds to the "fluffy" matter of the APOMC. The heterogeneous particles and partly finely dispersed matter come generally from disintegration of STOM, DOM and palynomorphs and indicate a terrestrial origin, whereas the "fluffy" matter indicates marine origin (Tyson, 1995).

The interpretation of depositional environments was made based on Bergen and Kerp (1990), Fijałkowska (1994, 1995), Fijałkowska-Mader et al. (2015a, b) and Tyson (1995).

\section{MINERALOGY AND BORON CONTENT OF THE FINE GRAINED ROCKS}

Twenty-two claystone and mudstone samples from the core interval of 899.11-1040.95 m of the Bartoszyce IG 1 borehole were examined in terms of bulk rock mineralogy, clay mineralogy and boron content (Fig. 4). Fifteen samples were taken from the Malbork Formation and seven from the Lidzbark Formation. Bulk rock compositions and clay minerals were identified by X-ray diffraction (XRD), using a Philips X'Pert PW 3020 diffractometer with CuK $\alpha$ radiation. The standard procedure of qualitative determination of minerals and semi-quantitative phase analysis based on ICDD (International Centre for Diffraction Data) database and Reference Intensity Ratio method was applied (as described e.g., by Brański, 2014). The results of 


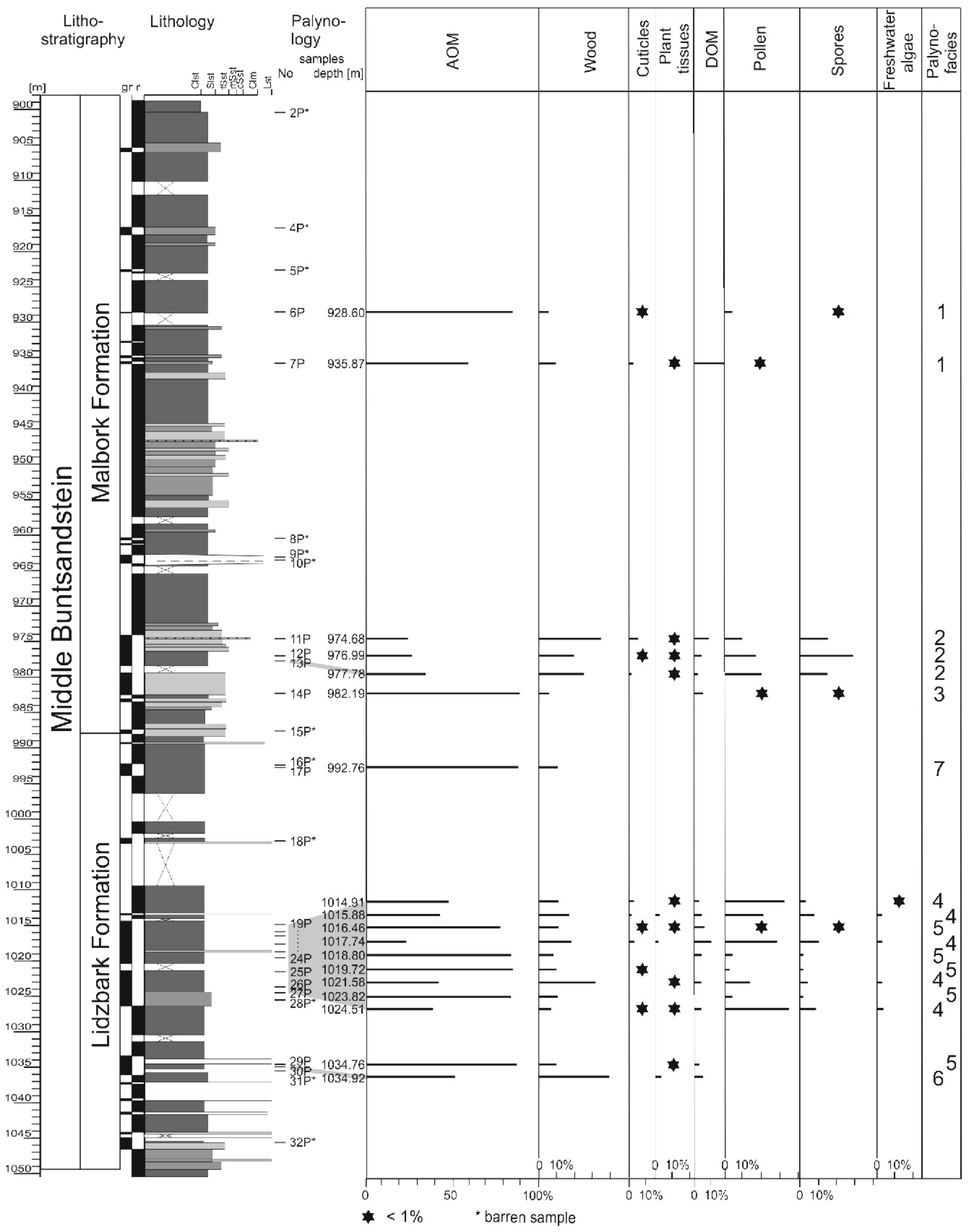

Fig. 7. Palynofacies analysis of the Middle Buntsandstein of the Bartoszyce IG 1 borehole

Explanation of lithology see Figure 4 
phase composition of individual specimens are provided in wt. $\%$, recalculated to $100 \%$ for each sample. The clay fraction $(<20 \mu \mathrm{m})$, obtained with the method based on differential settling from suspension, was identified from $X$-ray diagrams of oriented specimens after air-drying, glycol solvation, and heating at $550^{\circ} \mathrm{C}$. Semi-quantitative estimations of clay mineral content based on the peak areas of basal reflections characteristic for each mineral are provided in wt. \%.

Boron content was determined by inductively coupled plasma - optical emission spectrometry (ICP-OES) technique stepwise: first after hydrochloric acid digestion, and after digestion in aqua regia. For the first step $1 \mathrm{~g}$ of each sample was treated for $1 \mathrm{~h}$ in $95^{\circ} \mathrm{C}$ temperature with $25 \% \mathrm{HCl}$. The solution was filtered with a medium drain and distilled water was added to make a $50 \mathrm{~g}$ solution-specimen. For the second step $3 \mathrm{~g}$ of each sample was treated for $16 \mathrm{~h}$ at room temperature with aqua regia and then dissolved for a further $2 \mathrm{~h}$ under a reflux condenser. The sample was filtered with a medium drain and distilled water was added to make a $100 \mathrm{~g}$ solution-specimen. The measurements were conducted with an ICP-OES ICAP 6500 Duo Thermo Scientific spectrometer. The axial view and wavelengths of the $208.889 \mathrm{~nm}$ emission line was used for boron determination. Four point calibration in the linear range was applied. The low limit of detection was $5 \mathrm{mg} / \mathrm{kg}$. Control samples containing $100 \mathrm{mg} / \mathrm{kg}$ of boron, prepared with certified AccuStandard solutions, served as reference material.

All samples were examined at the Central Chemical Laboratory of the Polish Geological Institute - National Research Institute.

MICROFACIES, MINERALOGY AND GEOCHEMISTRY OF THE OOLITIC LIMESTONES

Fourteen samples of oolitic limestone were taken from the depth interval 1033.9-1045.3 m for petrographic and geochemical investigation (Fig. 4). The microfacies and petrographic analyses were based on polarizing microscopy, as well as cathodoluminescence $(\mathrm{CL})$ observations and scanning electron microscope analyses, made on thin sections prepared from each sample.

The chemical composition of the mineral phases was examined in spots and micro-areas of selected thin sections using the CAMECA SX 100 electron microprobe at the Micro-Area Analysis Laboratory of the Polish Geological Institute - National Research Institute. A total of 69 analyses were made. Detection limits (in ppm units) of the method for $\mathrm{Mg}$ was 45, for $\mathrm{Sr} \sim 350$, and for both $\mathrm{Mn}$ and $\mathrm{Fe}-240$. Most of the values measured were above the limits, except for a significant number of $\mathrm{Sr}$ analyses mainly of blocky calcite cements.

Carbon and oxygen stable isotopes analyses were performed on each sample with the Kiel IV Carbonate Device, connected to an IRMS Finnigan Delta Plus mass spectrometer, at the Stable Isotope Laboratory of the Institute of Geological Sciences of the Polish Academy of Sciences. Three of the 14 samples were analysed twice, the average value of both results being used.

\section{RESULTS}

\section{PALYNOFACIES OF THE LIDZBARK AND MALBORK FORMATIONS}

Seventy palynomorph taxa comprising spores, pollen grains and algae were identified and listed by Becker et al. (2020). Based on the proportion (in \%) of the particular palynoclast groups, seven types of palynofacies have been distinguished (Table 1; Figs. 7 and 8).
Palynofacies type 1 was recognized in the Malbork Formation at the depths of $928.60 \mathrm{~m}$ and $935.87 \mathrm{~m}$ (Fig. 7). It is dominated by finely dispersed particles (Fig. 8A). Less frequently occur wood, DOM and heterogeneous particles, with scarce pollen and individual spores and cuticles. Palynoclasts are predominantly yellow, light brown and black in colour (for details see Table 1).

Palynofacies type 2 was found in the Malbork Formation at the depths of $974.68 \mathrm{~m}, 976.99 \mathrm{~m}$ and $977.78 \mathrm{~m}$ (Fig. 7 and Table 1). It is characterized by a relatively high content of palynomorphs, reaching $50 \%$ (Fig. 8B) and the presence of freshwater algae. Wood and heterogeneous particles are abundant, whereas finely dispersed particles and DOM occur less frequently. Cuticles and plant tissues were seen very rarely. Palynoclasts vary in colour.

Palynofacies type 3 was recognized in the Malbork Formation at the depth of $982.19 \mathrm{~m}$ (Fig. 7 and Table 1). It is strongly dominated by black, opaque heterogeneous particles, whereas other palynoclasts, such as palynomorphs, wood and DOM are scarce (Fig. 8C).

Palynofacies type 4 occurs in the Lidzbark Formation at the depths of $1014.91 \mathrm{~m}, 1015.88 \mathrm{~m}, 1017.74 \mathrm{~m}, 1021.58 \mathrm{~m}$ and $1024.51 \mathrm{~m}$ (Fig. 7 and Table 1). It is distinguished by a high content of palynomorphs, reaching $45 \%$ (Fig. 8D), and the presence of freshwater algae. It differs from type 2 by the dominance of pollen over spores and the higher content of black heterogeneous particles.

Palynofacies type 5 was detected in the Lidzbark Formation at the depths of $1016.46 \mathrm{~m}, 1018.80 \mathrm{~m}, 1019.72 \mathrm{~m}, 1023.82 \mathrm{~m}$ and $1034.76 \mathrm{~m}$ (Fig. 7 and Table 1). Its distinctive feature is presence of the "fluffy" matter (Fig. 8E). The palynofacies is dominated by finely dispersed particles, whereas heterogeneous particles and wood occur less frequently. DOM and pollen are observed infrequently and other palynoclasts, such as spores, cuticles and plant tissues, sporadically.

Palynofacies type 6 occurs in the Lidzbark Formation at the depth of $1034.92 \mathrm{~m}$ (Fig. 7 and Table 1). It consists mainly of back, opaque heterogeneous particles and black wood. Finely dispersed particles, DOM and plant tissue are rare.

Palynofacies type 7 was found in the Lidzbark Formation, at the depth of $992.76 \mathrm{~m}$ (Fig. 7 and Table 1). It is strongly dominated by black AOM (mainly finely dispersed particles); black and dark brown wood particles occur less frequently (Fig. 8F).

MINERALOGY AND BORON CONTENT OF THE FINE-GRAINED ROCKS OF THE LIDZBARK AND MALBORK FORMATIONS

MINERALOGY

Clay minerals and quartz, reaching 34-65 wt.\% and $17-36$ wt. $\%$ of the bulk rock respectively, are the main components of the mudstones of the Lidzbark and Malbork formations in the Bartoszyce IG 1 borehole (Fig. 9). They are accompanied by feldspars, calcite and dolomite, which compose up to 31 wt.\% of the bulk rock. Dolomite occurs in all samples from the Lidzbark Formation and only in a few samples of the lowermost and uppermost parts of the Malbork Formation. By contrast, feldspars occur in all samples, reaching 7 to $11 \mathrm{wt} \%$ of the bulk rock. Traces of iron minerals have been found in most samples of the Malbork Formation. In the samples from 904-918 m depth they were represented by goethite. At 934-954 $\mathrm{m}$ depth hematite prevailed. In the sample from 1017.7 m depth (Lidzbark Fm.) 3 wt.\% gypsum occurs accompanied by the highest dolomite content (18 wt.\%) of all the samples examined.

Some differences can be observed between the samples of the Lidzbark Formation and the Malbork Formation with respect 
$\mathrm{T}$ a ble 1

Percentages of individual groups of palynoclasts and their colours for the distinguished types of palynofacies

\begin{tabular}{|c|c|c|c|c|c|c|c|}
\hline $\begin{array}{c}\text { Palynofacies } \\
\text { (Fig. 8) }\end{array}$ & $\begin{array}{l}\text { type } 1 \\
\text { (A) }\end{array}$ & $\begin{array}{l}\text { type } 2 \\
\text { (B) }\end{array}$ & $\begin{array}{l}\text { type } 3 \\
\text { (C) }\end{array}$ & $\begin{array}{l}\text { type } 4 \\
\text { (D) }\end{array}$ & $\begin{array}{l}\text { type } 5 \\
\text { (E) }\end{array}$ & type 6 & $\begin{array}{c}\text { type } 7 \\
\text { (F) }\end{array}$ \\
\hline \multicolumn{8}{|l|}{ Palynoclasts [\%] } \\
\hline \multicolumn{8}{|l|}{ Palynomorphs } \\
\hline spores & $0-0.5$ & $15-30$ & 0.2 & $3-10$ & $0-1$ & 0 & 0 \\
\hline pollen & $0.5-3$ & $10-20$ & 0.8 & $13-36$ & $0-3$ & 0 & 0 \\
\hline freshwater algae & 0 & $0-2$ & 0 & $0.2-3$ & 0 & 0 & 0 \\
\hline \multicolumn{8}{|l|}{ STOM } \\
\hline wood & $5-10$ & $20-35$ & 4 & $7-32$ & $8-12$ & 40 & 11 \\
\hline cuticles & $0.2-2$ & $0.5-5$ & 0 & $0.5-2$ & $0-0.5$ & 0 & 0 \\
\hline plant tissues & $0-0.1$ & $0.2-0.5$ & 0 & $0-2$ & $0-0.2$ & 4 & 0 \\
\hline DOM & $5-10$ & $5-10$ & 5 & $2-5$ & $2-6$ & 5 & 0 \\
\hline \multicolumn{8}{|l|}{ AOM } \\
\hline heterogeneous $p$. & $5-10$ & $10-30$ & 90 & $20-40$ & $10-20$ & 43 & 19 \\
\hline finely disp. p. & $60-85$ & $10-15$ & 0 & $5-10$ & $40-67$ & 8 & 70 \\
\hline "fluffy" matter & 0 & 0 & 0 & 0 & $20-40$ & 0 & 0 \\
\hline \multicolumn{8}{|l|}{ Colour [\%] } \\
\hline yellow & $20-30$ & $10-20$ & 0 & $10-20$ & $30-40$ & 0 & 0 \\
\hline orange & 0 & $0-10$ & 0 & $5-10$ & 0 & 0 & 0 \\
\hline light brown & $20-30$ & $20-30$ & 0 & $10-20$ & $20-30$ & 0 & 0 \\
\hline brown & $0-10$ & $2-10$ & 0 & $0-2$ & $0-3$ & 0 & 0 \\
\hline dark brown & $5-10$ & $10-20$ & 5 & $10-20$ & $10-20$ & 2 & 5 \\
\hline black (opaque) & $20-30$ & $20-30$ & 95 & $30-60$ & $20-40$ & 98 & 95 \\
\hline
\end{tabular}

disp. - dispersed, p. - particles

to the main rock components. In the samples of the Lidzbark Formation quartz content rarely exceeds $20 \mathrm{wt} . \%$, while in the Malbork Formation it is higher and varies between 24 wt. $\%$ and 36 wt. \% (Fig. 9). The clay mineral content is stable and reaches $\sim 50$ wt.\% in the Lidzbark Formation and the lowermost part of the Malbork Formation, while it is variable in the middle and upper parts of the Malbork Formation, ranging from $33 \mathrm{wt} \%$ to 65 wt.\%, with an average of 48 wt.\% (Fig. 9).

In all samples investigated, the clay mineral association is composed of chlorite, making up 15-29 wt.\% of the bulk rock, and illite or a mixture of illite and smectite (illite prevails, except for one sample), reaching 16 to $45 \mathrm{wt} . \%$, most often $\sim 30 \mathrm{wt} . \%$ (Fig. 9). The highest amount of chlorite (>20 wt.\%) was found in the middle part of the Malbork Formation, at a depth of 918.32-954.60 m. Illite occurs, as the second component of the clay mineral association, in the samples of the Lidzbark Formation and the lowermost part of the Malbork Formation. The mixture of illite and smectite comprises the second component in the samples of the middle and upper parts of the Malbork Formation. The boundary between the two associations is recognizable and lies between the samples at $950.72 \mathrm{~m}$ and $954.6 \mathrm{~m}$ depth ( 952.66 m; Fig. 9).

According to Nowicka (1974a) quartz, feldspars and chlorite belong to the detrital components of the rocks, whereas calcite, dolomite, illite and iron hydroxides form its matrix.

A full dataset is provided in the supplementary material attached as an Excel file (Appendix $1^{*}$ ).

\section{BORON CONTENT}

The boron content obtained after the $\mathrm{HCl}$ digestion of samples varies between 44 and $112 \mathrm{mg} / \mathrm{kg}$ across all samples investigated, and a poorly defined overall drop in values towards the top of the succession can be observed (Fig. 9). The average value below the depth of $968.77 \mathrm{~m}$ reaches $81.8 \mathrm{mg} / \mathrm{kg}$ and does not exceed $65 \mathrm{mg} / \mathrm{kg}$ higher in the section. The highest values occur in the depth interval of 977.29-1017.7 m.

The boron content obtained after aqua regia dissolution of samples varies between 70 and $121 \mathrm{mg} / \mathrm{kg}$ across all samples examined (Fig. 9). All but one result above the depth of $963.28 \mathrm{~m}$ shows values of $>90 \mathrm{mg} / \mathrm{kg}(110.3 \mathrm{mg} / \mathrm{kg}$ in average), while below this depth the values vary between 76 and $118 \mathrm{mg} / \mathrm{kg}$ (average $86.5 \mathrm{mg} / \mathrm{kg}$ ). A vague but overall increasing trend can be observed towards the top of the succession. Despite the general trend, the succession can be divided into subsections of higher and lower boron content. The lower boron content is characteristic of the intervals 1021.48-1040.95 m and $954.6-968.77 \mathrm{~m}$. The higher values occur in the intervals 977.29-1017.7 $\mathrm{m}$ and 899.11-950.72 $\mathrm{m}$.

The values achieved after the second dissolution step are generally higher than those measured after the first step. The results between the two steps show opposite trends to the top of the succession. As a result, the difference in boron content obtained after the second and the first steps of sample digestion is significantly higher in the upper part of the succession than in the lower one. For the average values below the depth

* Supplementary data associated with this article can be found, in the online version, at doi: 10.7306/gq.1566 

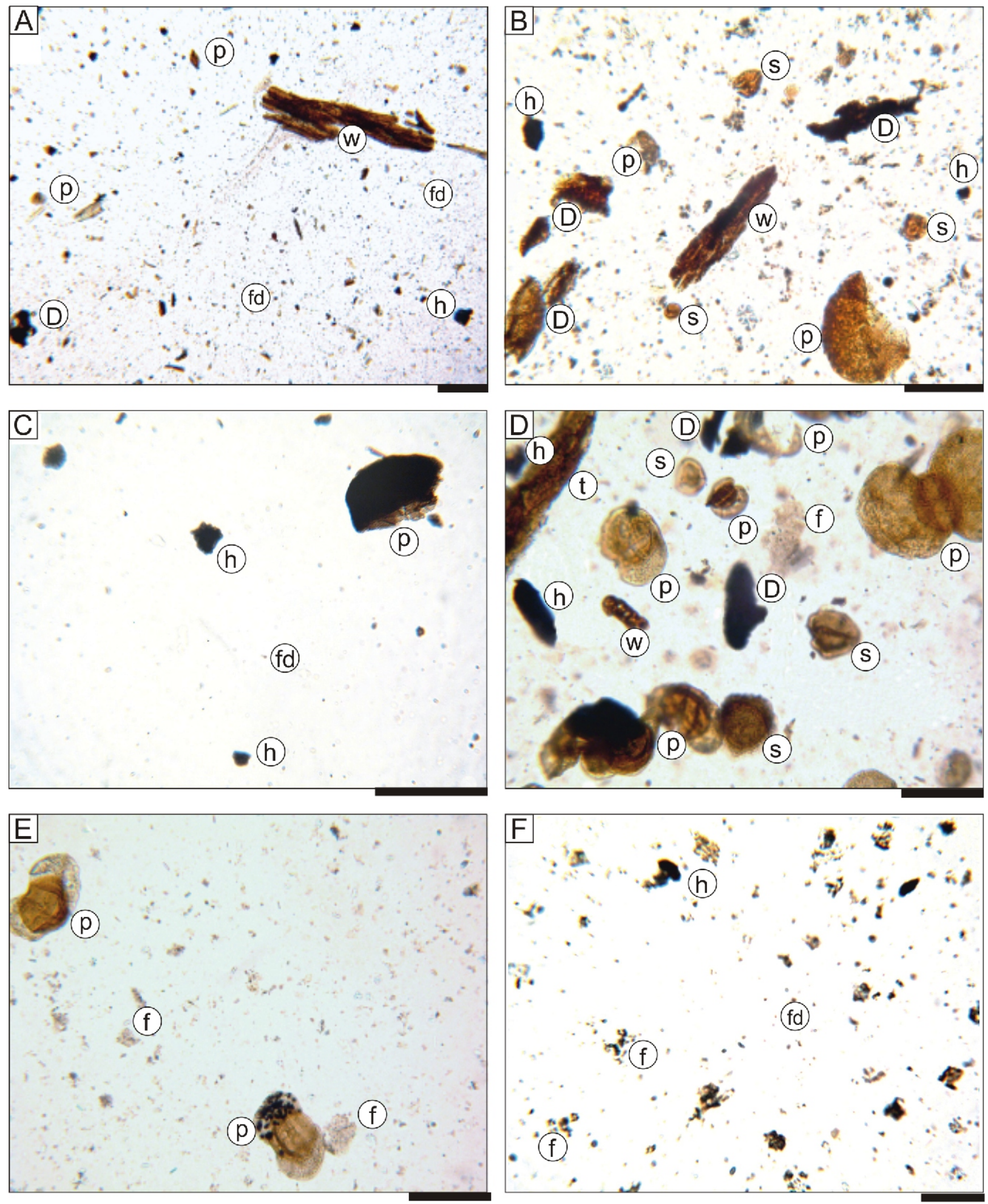

Fig. 8. Palynofacies of the Middle Buntsandstein of the Bartoszyce IG 1 borehole

A - type 1; floodplain, distal zone, depth 935.87 m, Malbork Fm.; B - type 2, floodplain, proximal zone, 974.68 m, Malbork Fm.; C - type 3 , probable deltaic or barrier setting, 982.19 m, Malbork Fm.; D - type 4, brackish lagoon, depth $1024.51 \mathrm{~m}$, Lidzbark Fm.; E - type 5, open marine basin, depth $1019.72 \mathrm{~m}$, Lidzbark Fm.; F - type 7, open marine palynofacies, probably pedogenically altered, depth $992.76 \mathrm{~m}$, Lidzbark Fm.; palynoclasts: D - DOM, f - "fluffy" matter, fd - finely dispersed particles, $h$ - heterogeneous particles, $p$ - pollen, $s$ - spores, $t$ - plant tissues, $\mathrm{w}$ - wood; scale bar $60 \mu \mathrm{m}$ 
LithoLithology

stratigraphy

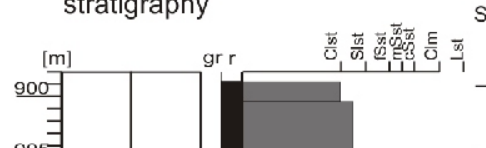$$
9
$$
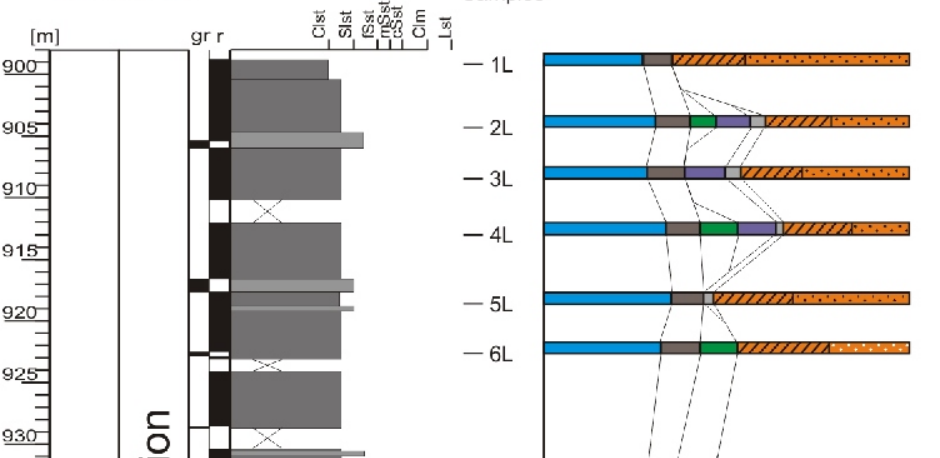

$-2 \mathrm{~L}$

$-3$

$-4$

$-5 \mathrm{~L}$

$-6 \mathrm{~L}$
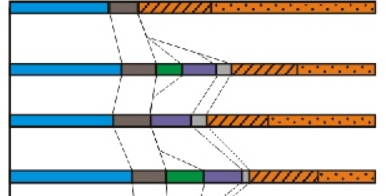

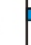

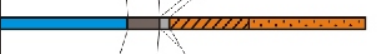

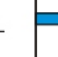

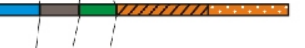

94.

955

960

$970^{970}$

gro

青 喜

들

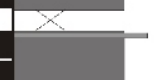

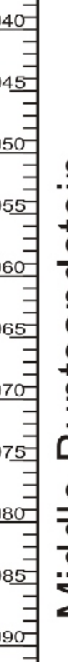
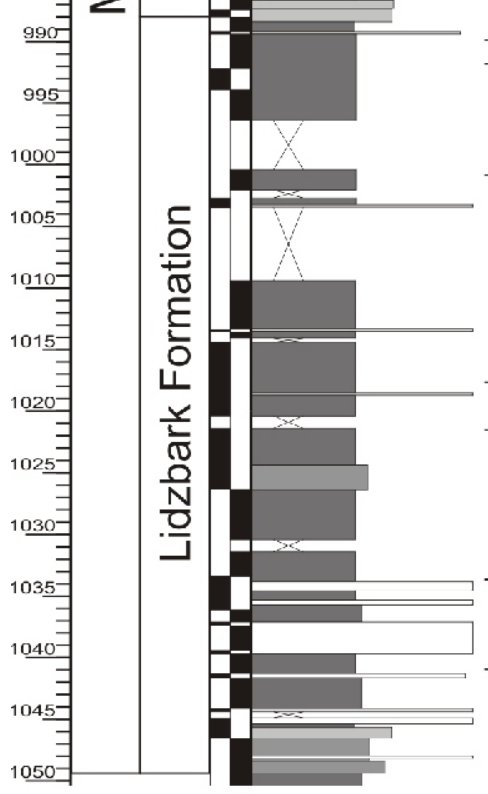

$-7 L$

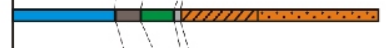

$-8 \mathrm{~L}$

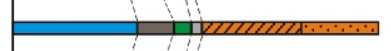

$\frac{1}{2}$
믐
$\frac{0}{\pi}$
$\sum$
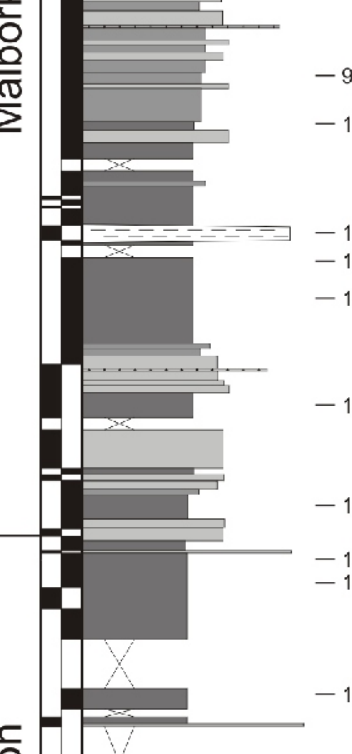

$18 \mathrm{~L}$

$-9 \mathrm{~L}$
$-10 \mathrm{~L}$

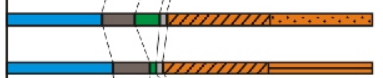

$-$

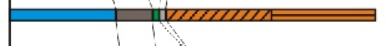

$-11 L$
-12

$-13$
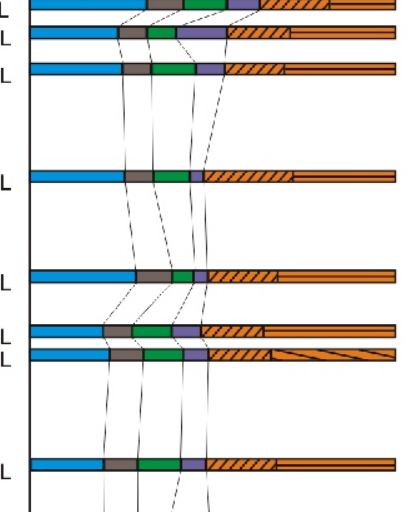

$-20 \mathrm{~L}$

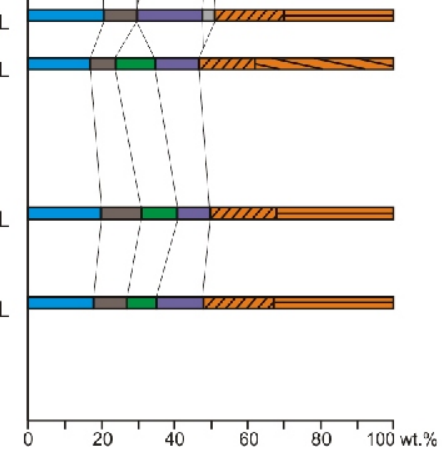

Boron

content

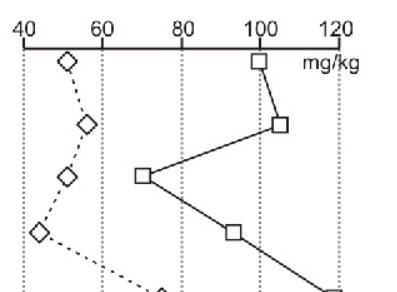

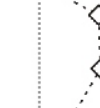

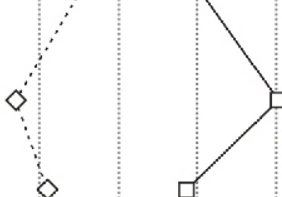

quartz

$\square$ feldspar

$\square$ calcite

$\square$ dolomite

$\square$ other

$\square$ clay minerals

$\checkmark$ illite and illite+smectite

$\succeq$ illite

illite+smectite

smectite+illite

was chlorite

Fig. 9. Results of mineralogical and geochemical investigation of fine-grained deposits of the Bartoszyce IG 1 borehole

Explanations as on Figure 4 
of $968.77 \mathrm{~m}$, the difference is $\sim 5 \mathrm{mg} / \mathrm{kg}$, while above the depth of $954.6 \mathrm{~m}$ it increases to $>40 \mathrm{mg} / \mathrm{kg}$.

A full dataset is provided in the supplementary material attached as an Excel file (Appendix 1).

MICROFACIES, MINERALOGY AND GEOCHEMISTRY OF THE OOLITIC LIMESTONES OF THE LIDZBARK FORMATION

The carbonate deposits within the Lidzbark Formation studied are exclusively oolitic limestones-mainly grainstones and rarely packstones (see Figs. 10 and 11). The grains in specific oolitic beds may be well or poorly sorted (Fig. 10A-E). Some limestone beds contain a greater or lesser admixture of quartz grains (see Fig. 10E).

The individual ooids are usually spherical and their diameter ranges from several dozen to $\sim 500 \mu \mathrm{m}$, often in the range of 300-400 $\mu \mathrm{m}$. In some beds, however, ooids have a diameter of up to $2 \mathrm{~mm}$ (e.g., sample 14 - Fig. 10B). There are various types of ooids: mostly radial and rarely concentric (tangential), or micritic (Fig. 10). Large radial ooids typically show well-developed extinction crosses in cross-polarized light (see Fig. 10C). The ratio of the thickness of the cortex to the nucleus in the ooids is very high. Ooid nuclei are either peloids or other unidentifiable micritic grains (Fig. 11A); often the growth of ooids took place on very small grains that are virtually unrecognizable. Compound ooids (ooid aggregates) and regenerated ooids are rare. No ooids with a core of a quartz grain or other terrigenous material were detected.

The oolitic deposits studied are almost completely devoid of fossils or bioclasts. The only organogenic residues that were visible in the thin sections analysed were several rounded skeletal fragments (just a couple of specimens in 14 thin sections) of non-specified organisms with apatite mineralogy (see Figs. 10F and 11D) and, even more rarely, carbonate shells of gastropods, ?bivalves, and ?ostracods.

The diagenetic processes affecting the oolitic deposits investigated comprise: cementation, dissolution as well as mechanical and chemical compaction (dissolution under pressure); in addition, clear evidence of recrystallization can be observed in some of the oolitic limestone beds examined.

Two types of calcite cement were found in the oolitic limestones. The first is an isopachous cement that forms thin rims around the ooids made of acicular calcite crystals, non-luminescent in CL (see Figs. 10C, D and 11A, B). The second, later type of cement is of coarsely crystalline blocky calcite (crystals up to several tens of micrometres in size - see Fig. 11A-C) that shows intense cathodoluminescence (see Fig. 10D). Dissolution of unstable carbonate mineral phases has been observed in rare cases (Fig. 10A). The effects of mechanical compaction are broken or cracked ooids and bioclasts (see Fig. 10D). Chemical effects of compaction by pressure solution is shown by the presence of stylolite sutures and a concavo-convex pattern (indentations) at the contacts of neighbouring ooids (see Figs. 10E and 11C).

Analyses by a CAMECA SX 100 electron microprobe showed that the oolitic deposits are almost exclusively composed of low-magnesium calcite. Locally dolomite was found in some of the samples investigated. It forms thin laminae or tiny "splashes" in ooids and small peloids or micritic intraclasts (Fig. 11). Except for dolomite, other authigenic minerals found in the limestones studied are celestite (often as cement - large crystals in pores - see Fig. 11C), barite, silica, and pyrite. Detrital minerals in addition to quartz include feldspars (potassium feldspar and plagioclase), apatite, clay minerals, zircon and garnet (Fig. 11).
No significant difference in mineralogical or chemical composition was found between the calcite forming ooids and acicular rim cements (see Table 2). Ooid cortices contain on average $\sim 0.51 \mathrm{wt} . \% \mathrm{Mg}$ (from 0.288 to $0.637 \mathrm{wt} \%$ ) and almost 0.05 wt. $\%$ Sr (max. up to 0.065 wt.\%). Mean Mn content is $\sim 0.06$ wt. \% (from 0.027 to 0.093 wt. $\%$ ) and mean Fe content is nearly 0.24 wt. $\%$ (from $\sim 0.09$ to 0.42 wt. $\%$ ). The chemical composition of the acicular rim cement is similar. Its mean Mg content reaches $0.41 \mathrm{wt} . \%$ (max. up to $0.60 \mathrm{wt} . \%$ ), mean Sr content is $0.05 \mathrm{wt} . \%$ (and varies in a broad range with a max. value of 0.088 wt. \%), mean Mn content is $\sim 0.06$ wt. \% (from 0.027 to 0.093 wt. \%) and mean Fe content is $\sim 0.13$ wt. \% (from 0.078 to 0.177 wt.\%). The blocky calcite cement is clearly different in chemical composition than both ooids and acicular rim cement. It contains less $\mathrm{Mg}$ (mean $\sim 0.29 \mathrm{wt} \%$, ranging from 0.040 to 0.481 wt. $\%$ ), Sr (most results below detection limit of 0.0350 wt.\%; only two analyses out of a total of 37 are above the limit reaching $\sim 0.04$ wt. \%), $\mathrm{Fe}$ (mean almost 0.08 wt. \% - from 0.014 to 0.167 wt. \%) and more $\mathrm{Mn}$ (mean 0.144 wt. $\%$ - from 0.033 to 0.203 wt.\%). Additionally, the blocky cement is very poor in $\mathrm{Si}$, $\mathrm{Al}$ and $\mathrm{S}$ compared to the other components (Table 2).

Mean elemental contents of $\mathrm{Mg}, \mathrm{Sr}, \mathrm{Mn}$, and Fe measured by electron microprobe in the individual calcite mineral phases and in the dispersed dolomite are given in Table 2. A full set of analyses (including some basic statistical data) is provided in the supplementary material attached as an Excel file (Appendix 2).

The measured values of $\delta^{18} \mathrm{O}$ and $\delta^{13} \mathrm{C}$ are plotted in Figure 12. $\delta^{18} \mathrm{O}$ values in the samples examined are very homogeneous and cover an approximate range from -5 to $-4.5 \%$ o VPDB (Fig. 12). Out of a total of 17 isotope analyses, only two samples taken from the lowermost oolitic bed show a value of $\delta^{18} \mathrm{O}$ above $-4 \%$ VPDB. The $\delta^{13} \mathrm{C}$ values range from -2 to $+1 \%$ o VPDB (Fig. 12). The most striking feature is a distinct decrease in $\delta^{13} \mathrm{C}$ (= increasing contribution of light biogenic ${ }^{12} \mathrm{C}$ isotope) up the section. A complete list of analyses is provided in the supplementary material attached as an Excel file (Appendix 3 ).

\section{DISCUSSION}

\section{PALYNOFACIES - PALAEOENVIRONMENTAL CONTEXT}

The palynofacies may be initially interpreted in terms of its different types as regards the environmental processes which may have led to the their development.

Palynofacies type 1, which occurs in the middle part of the Malbork Formation, is strongly dominated by finely dispersed particles of AOM of terrestrial derivation (e.g., Batten, 1996) and does not contain marine palynoclasts. This points to a terrestrial environment with low preservation potential for palynomorphs. A similar palynofacies was described as type 5 by Fijałkowska (1994) from Lower Triassic distal alluvial plain deposits in the Holy Cross Mountains and as type 2 from Upper Triassic floodplain deposits in Upper Silesia (FijałkowskaMader et al., 2015a).

Palynofacies type 2 palynofacies, occurring in the lower part of the Malbork Formation, is characterized by a high content of palynomorphs and structural matter, which indicates proximity to land (Tyson, 1995) and a good preservation potential for organic matter. Hence palynofacies type 2 was deposited in a location relatively close to plant communities and possibly under less oxidizing conditions than type 1 . Such conditions may be fulfilled on frequently flooded parts of a floodplain or a delta plain. 

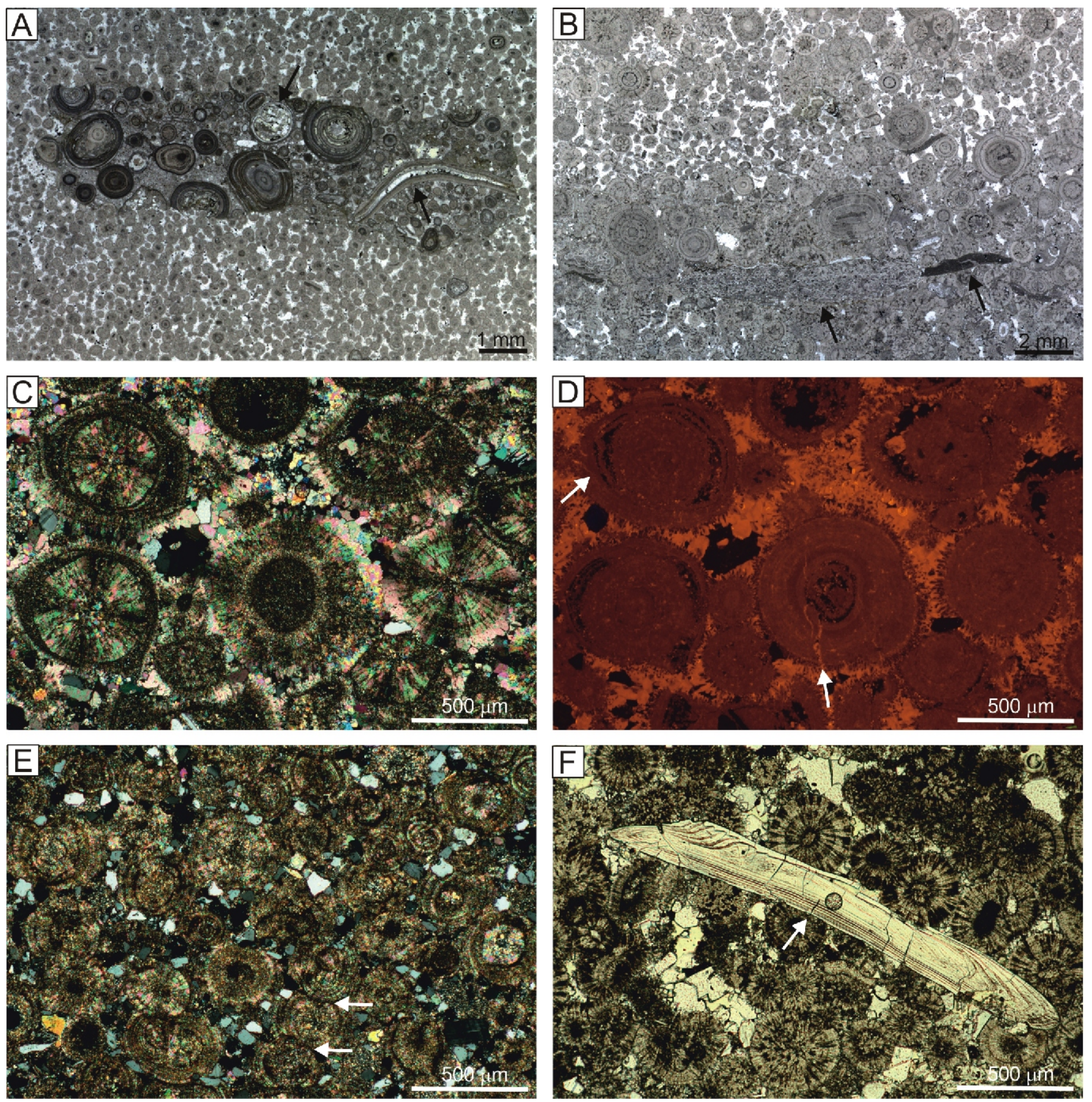

Fig. 10. Examples of microfacies and microstructures of oolitic limestones of the Lidzbark Fm. of the Bartoszyce IG 1 borehole

A - fine-grained oolitic grainstone with large intraclast of coarse-grained oolitic packstone containing now-dissolved gastropod and ?bivalve shells (arrows) that are occluded with late-diagenetic calcite cements, the bivalve shell is rimmed with an oolitic coating (sample no. 8, depth $1038.8 \mathrm{~m}$, plane-polarized light microphotograph); B - poorly sorted oolitic grainstone with intraclasts of wackestone (containing tiny thin shells of ?ostracods) and mudstone (arrows) (sample no 14, depth $1033.9 \mathrm{~m}$, plane-polarized light microphotograph); C, D - poorly sorted oolitic grainstone composed of radial ooids (see well-developed extinction crosses in some ooids), it is extensively cemented by two cement generations: the first is a synsedimentary fibrous rimmed calcite cement syntaxially overgrowing the ooids, the second is coarse-crystalline blocky calcite cement of meteoric or burial origin, crushed or cracked ooids (arrows) are indicative of mechanical compaction (sample no 3 , depth $1041.6 \mathrm{~m}$, crossed polars and cathodoluminescence $(\mathrm{CL})$ microphotographs, respectively; $\mathbf{E}$ - fine-grained oolitic packstone with numerous usually angular quartz grains; stylolite sutures and concavo-convex indentations at the ooid-to-ooid contacts (arrows) are indicators of compaction (sample no 1, depth $1045.30 \mathrm{~m}$, crossed polars microphotograph); $\mathbf{F}$ - oolitic grainstone containing a skeletal element (arrow) of an undefined organism (possibly a fish scale) of apatite mineralogy (sample no 3, depth $1041.6 \mathrm{~m}$, plane-polarized light microphotograph) 

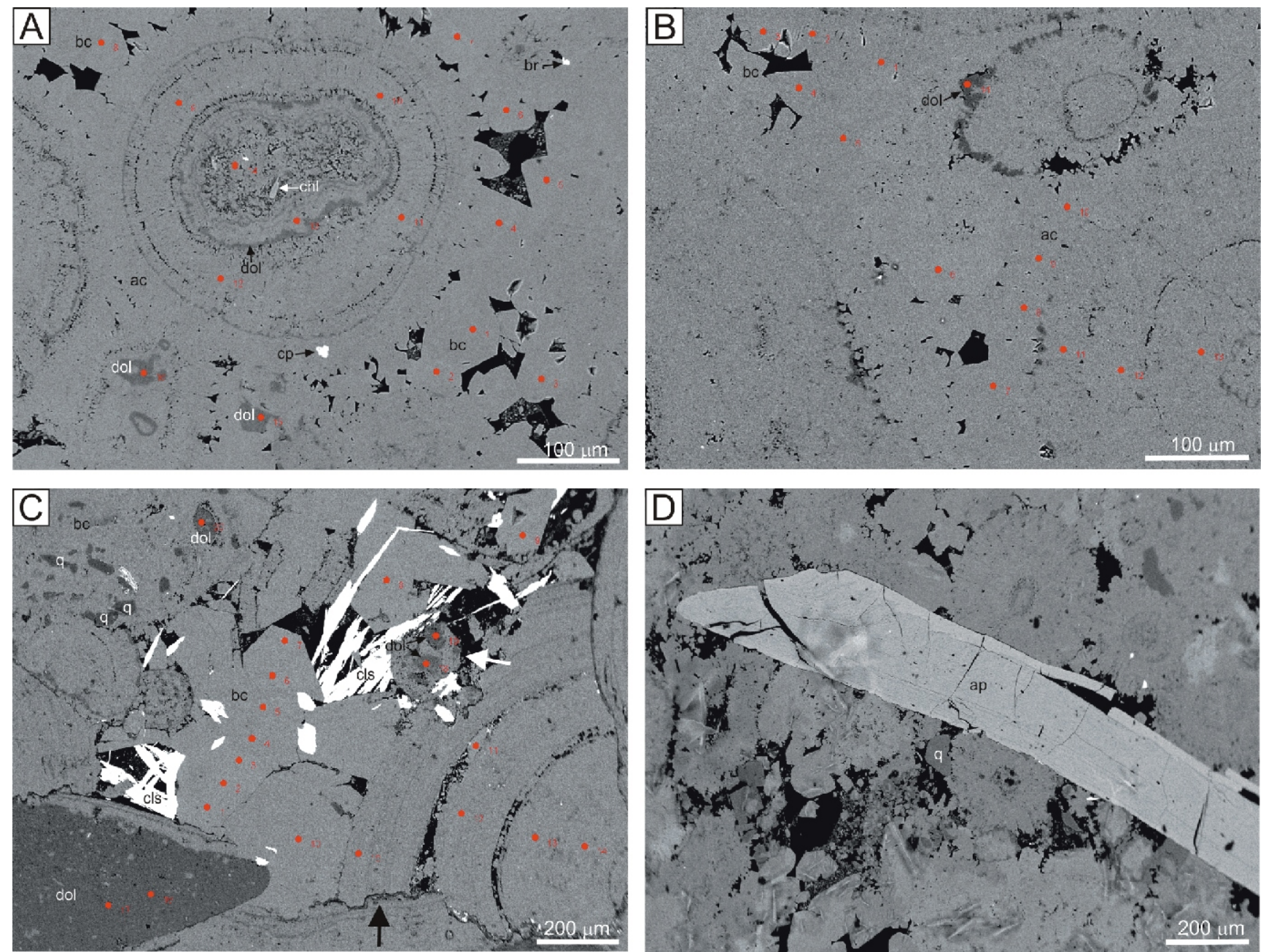

Fig. 11. Oolitic limestones in BSE (backscattered-electron) images

A, B - oolitic grainstone with acicular rim cement and blocky calcite cement, thin dolomitic laminae within ooid cortices highlight the concentric ooid structure, dolomite forms also irregular patches within the ooids (sample no. 3, depth 1041.6 and sample no. 7, depth 1039.0, respectively); C - oolitic grainstone with large dolomicritic intraclast (bottom left), partly dolomitized peloids (white arrow) and individual grains of detrital quartz, large ooid is heavily dissolved by stylolite (black arrow), intergranular porosity is filled with blocky calcite and celestite cements (sample no 14, depth 1033.9); D - oolitic grainstone with undefined skeletal element of apatite mineralogy (sample no 3, depth 1041.6); red dots mark points of CAMECA SX 100 analyses; dol - dolomite, bc - blocky calcite cement, ac - acicular rim cement, ap - apatite, $\mathrm{br}$ - barite, cls - celestite, $\mathrm{cp}$ - chalcopyrite, chl - chlorite

Mean content of selected elements in individual calcite phases and in dolomite

\begin{tabular}{|c|c|c|c|c|c|c|c|c|}
\hline Component & $\begin{array}{c}\text { No. of } \\
\text { analyses }\end{array}$ & $\begin{array}{c}\mathrm{Mg} \\
\text { [wt.\%] }\end{array}$ & $\begin{array}{c}\mathrm{Sr} \\
\text { [wt.\%] }\end{array}$ & $\begin{array}{c}\text { Mn } \\
\text { [wt.\%] }\end{array}$ & $\begin{array}{c}\mathrm{Fe} \\
\text { [wt.\%] }\end{array}$ & $\begin{array}{c}\mathrm{Al} \\
\text { [wt.\%] }\end{array}$ & $\begin{array}{c}\mathbf{S i} \\
\text { [wt.\%] }\end{array}$ & $\begin{array}{c}\text { S } \\
\text { [wt.\%] }\end{array}$ \\
\hline ooid cortex & 17 & 0.508 & 0.046 & 0.066 & 0.238 & 0.139 & 0.373 & 0.069 \\
\hline acicular rim cement & 4 & 0.415 & 0.050 & 0.064 & 0.127 & 0.002 & 0.080 & 0.033 \\
\hline blocky cement & 37 & 0.289 & 0.018 & 0.144 & 0.077 & 0.002 & 0.031 & 0.019 \\
\hline dolomite & 9 & 11.613 & 0.026 & 0.107 & 1.025 & 0.253 & 0.554 & 0.043 \\
\hline \multicolumn{2}{|c|}{ detection limit [wt.\%] } & 0.0045 & 0.035 & 0.024 & 0.024 & 0.006 & 0.0065 & 0.0065 \\
\hline
\end{tabular}




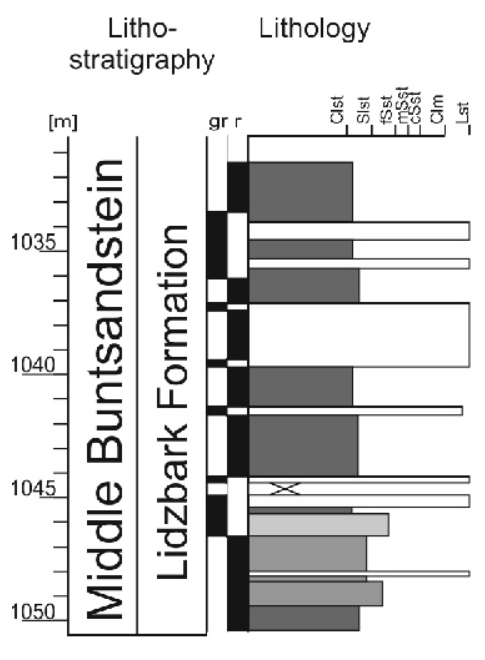

$\delta^{18} \mathrm{O}$
$(\% \circ \mathrm{VPDB})$

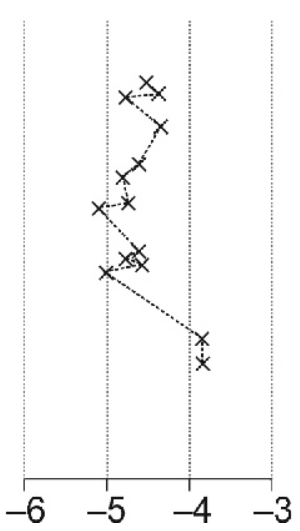

$\delta^{13} \mathrm{C}$

$(\% \circ \mathrm{VPDB})$

Fig. 12. Results of oxygen and carbon stable isotope measurements of the Lidzbark Formation oolitic limestones

Explanations as on Figure 4

Palynofacies type 3, which occurs within the sandy interval of the basal Malbork Formation, interpreted as deltaic or barrier in origin (see Fig. 4), consists almost entirely of amorphous organic matter in the form of black, opaque heterogeneous particles with a small amount of wood and very rare individual palynomorphs. Such a composition can indicate long transport and/or redeposition of the organic matter (Tyson, 1995). Numerous studies summarized by Tyson $(1993,1995)$ show a clear connection between high ratios of opaque phytoclasts and relatively coarse-grained, high energy, organically-poor facies, especially in deltaic systems.

The palynoclast composition of palynofacies type 4, occurring in the lower part of the Lidzbark Formation, with a relatively high amount of palynomorphs and STOM, as well as the presence of freshwater algae and lack of marine plankton and "fluffy" matter, may indicate deposition in a brackish lagoon (e.g., Bergen and Kerp, 1990; Pieńkowski and Waksmundzka, 2009; Heunisch et al., 2010).

Palynofacies type 5 is the only one where "fluffy" amorphous organic matter occurs. This, together with the lack of freshwater algae, may indicate a marine origin for this type of palynofacies (e.g., Tyson, 1995; Batten, 1996).

Palynofacies type 6, occurring in coarser grained, sandy-oolitic layer in the lower part of the Lidzbark Formation, consists mainly of heterogeneous particles and wood and indicates input of terrigeneous material into the basin after relatively long transport (e.g., Batten, 1996).

The origin of the type 7 palynofacies, recognized in a pedogenically altered mudstone in the topmost Lidzbark Formation, is an unsolved problem. It consists almost entirely of amorphous organic matter in the form of black, opaque finely dispersed or heterogenous particles with a small amount of wood. Such a composition of the palynofacies could result from post-depositional oxidation associated with longer emergence periods, which are documented by initial pedogenic processes (staining, roots, massive structures; cf. Tyson, 1993, 1995). Diagenetic, possibly thermal, decomposition of primary organic matter may also be considered, but is less likely.

The vertical succession of palynofacies reflects well the generally shallowing upwards trend in the depositional environments. Palynofacies type 5 is gradually replaced by type 4 within the lower Lidzbark Formation, which is accompanied by a decline in ooidal shoals/bars sedimentation in favour of calm deposition in shallow water. Progressive regression lad to the initial development of palaeosols at the end of sedimentation of the Lidzbark Formation accompanied by type 7 palynofacies. Then sedimentation of the Malbork Formation began in a deltaic and proximal floodplain setting associated with palynofacies types 3 and 2 . During sedimentation of the middle part of the Malbork Formation, the alluvial plain area increased and type 1 palynofacies appeared.

Palynofacies analysis did not provide any clear arguments for marine depositional environments. In contrast to the lowermost Middle Buntsandstein deposits of the central part of the CEB, no acritarchs or even prasinophyts were found in the sediments investigated (e.g., Orłowska-Zwolińska, 1984; Heunisch and Röhling, 2016). The presence of "fluffy" amorphous organic matter within the type 5 palynofacies found in the lower part of the Lidzbark Formation is the only argument for a possible marine origin (e.g., Tyson, 1995; Batten, 1996). Terrestrial, fluvial environment of the Malbork Formation, especially of its upper part, is well-documented.

MINERALOGY AND BORON CONTENT OF THE FINE-GRAINED ROCKS VERTICAL AND REGIONAL DIFFERENTIATION, PALAEOGEOGRAPHICAL CONTEXT AND DIAGENESIS

MINERALOGY

The mineralogy of the fine-grained deposits of the Lidzbark Formation and the lowermost part of the Malbork Formation is significantly more uniform than that of the upper part of the Malbork Formation. The hydrological and chemical conditions were therefore stable over a long period of time during deposition of the lower part of the succession under discussion, which is to be expected for marine as opposed to continental settings (Sheldon and Tabor, 2009). A typical feature of a playa lake basin should be its recurring contraction associated with changes in the chemical conditions of deposition (e.g., Kendall, 1984 in Talbot and Allen, 1996; Briere, 2000). One may expect a more varied mineralogical signal from a succession deposited in a system of such persistent environmental fluctuations (Last, 
1984; Schütt, 2004; Rahimpour-Bonab and Abdi, 2012). Enrichments in hematite and goethite accompanied by calcite, as well as calcareous nodules and stains (mottles), typical of immature soils, e.g. vertisols (Sheldon and Tabor, 2009; Środoń et al., 2014) only occur in the uppermost part of the Malbork Formation and document pedogenic processes in a continental realm

The pattern of dolomite distribution within the vertical succession of the Middle Buntsandstein is also significant. Dolomite occurs in all samples below the depth of $963 \mathrm{~m}$, i.e. in the lowermost part of the Malbork Formation and through the entire Lidzbark Formation. Above, within the upper part of the Malbork Formation, dolomite only accompanies goethite enrichments. Driese et al. (2000) listed the dolomitization of pedogenic calcite as one of the typical mineralogical changes associated with the burial diagenesis of a palaeo-vertisol. There are indications of pedogenic processes within the upper part of the Malbork Formation. Enrichment in calcite and iron oxides (hydroxides) is typical of immature soil horizons (e.g., Sheldon and Tabor, 2009; Środon et al., 2014). Thus the dolomite in the upper part of the Malbork Formation is probably of diagenetic origin. The origin of the dolomite within the Lidzbark Formation was rather different than that of the Malbork Formation. There is no evidence of pedogenic processes throughout most of the Lidzbark Formation. Środoń et al. (2014) hypothesized marine incursions based on the presence of dolomite and its isotopic signal in the mudstones of the Upper Triassic. According to current environmental models (playa lake vs. epicontinental sea) the Lidzbark Formation had to be deposited in brackish to saline water (e.g., Iwanow and Kiersnowski, 1998; Paul, 1999a; Szulc, 2019). The dolomite pattern fits this interpretation, as dolomite occurs more often in marine deposits or in deposits of saline lakes (including playa lakes) than in freshwater deposits (Riding, 1996). In a playa lake environment, stronger salinity fluctuations would be expected than in a relatively stable marine environment, which contradicts the observed stable dolomite content. Nevertheless, a diagenetic origin for the dolomite cannot be excluded. Further investigations, including dolomite forms and isotopic composition, are needed to determine the source and origin of dolomite in the Lidzbark Formation.

The clay mineralogy of the Buntsandstein mudstones was previously investigated by Szamałek (1989) in southern Poland (the Holy Cross Mts. region) and by Czapowski et al. (1994) in southwestern Poland. Brański (2007) provided additional results from an exposure in southern Poland. Clay mineral associations vary regionally (Fig. 13). Czapowski et al. (1994) recorded a dominance of kaolinite over illite, chlorite and subordinate smectite in southwestern Poland. In southern Poland Brański (2007) reported a clay mineral assemblage of kaolinite and illite dominant over smectite and chlorite. The results of Szamałek (1989) show a clay mineral assemblage in which illite dominates over kaolinite and subordinate chlorite. He found no smectite. Finally, recent results show an assemblage with a dominance of illite over chlorite and subordinate smectite without kaolinite. A noticeable systematic decrease in the kaolinite content can be observed between southwestern and northeastern Poland. Kaolinite abundance is typically interpreted as dependent on the climatic conditions of rock weathering and/or on the proximity of basin margins and source rocks (see e.g., Brański, 2012, 2014; Środoń et al., 2014 with references therein). Weathering products formed under more humid conditions are enriched in kaolinite (e.g., Chamley, 1989; Thamban et al., 2002). However, the kaolinite particles are larger than those of illite and illite-smectite, so that enrichments in kaolinite are associated with the basin margins (see Środoń et al., 2014

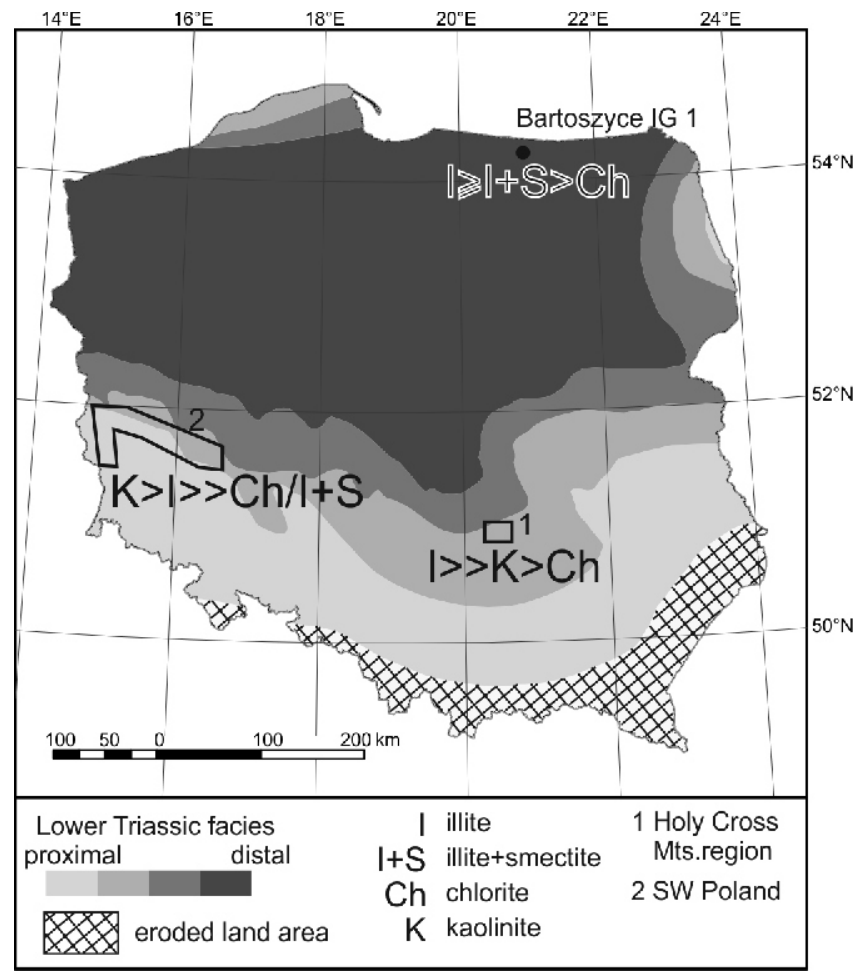

Fig. 13. Regional differentiation of clay mineral assemblages within the Buntsandstein mudstones of Poland. Overall facies distribution after Iwanow and Kiersnowski (1998), modified; clay mineralogy of the Holy Cross Mountains region after Szamałek (1989) and Brański (2007) and of southwestern Poland after Czapowski et al. (1994)

with references therein). The Buntsandstein mudstones examined from different parts of Poland are not precisely isochronous. Nevertheless, they represent the Lower (SW Poland) and Middle (south-central and NE Poland) Buntsandstein, and are all dated as deposited in the Induan or early Olenekian (Becker et al., 2008, 2020). Since the observed kaolinite trend is spatial rather than temporal, NE Poland represents the most distal position within the Early Triassic basin of Poland. This fits well with the former interpretation of facies distribution (see Fig. 13; Iwanow and Kiersnowski, 1998) and supports the inference that kaolinite enrichments may indicate proximity to land. The trend observed is an additional argument that the basin was controlled by connection to the north with an open marine realm rather than to the south, if any (Szulc in Beutler and Szulc, 1999; Becker, 2005; Szulc, 2019). Nevertheless a similar facies pattern and kaolinite trend could be expected for a hydrologically closed intracontinental playa-lake basin (Paul, 1982, 1999a; Rahimpour-Bonab and Abdi, 2012).

A systematic development of clay-mineral assemblages can be observed within the Middle Buntsandstein succession investigated. Smectite disappears with depth and is replaced by illite, rarely with an additional mixed-layered illite-smectite mineral. In addition to the lack of kaolinite, this indicates diagenetic illitization (cf. e.g., Brański, 2012; Środoń et al., 2014). According to Chamley (1989), a significant diagenetic overprint, including the illitization of smectite, begins when the burial depth exceeds $\sim 2000 \mathrm{~m}$. Dyrka (2014) interpreted the maximum burial depth of the Lower Triassic in north-eastern Poland to only $1200 \mathrm{~m}$. The colours of spores examined also indicate a relatively low degree of thermal alteration. The assumed illitization 
could be a product of hydrothermal alteration caused by K-rich fluids and not burial diagenesis as is inferred for the Keuper mudstones in southern Poland as well (Środoń et al., 2014). Zechstein deposits located to the west of the Bartoszyce area underlying the Buntsandstein, may be the source of K-rich fluids. Permian K-salt deposits are documented $\sim 50 \mathrm{~km}$ to the west (Szuflicki et al., 2019) of the site investigated, and Stolarczyk (1972) suspected K-salt occurrences not more than $20 \mathrm{~km}$ west of it. The area of northeastern Poland was affected by a hydrothermal event, which is documented by the uranium deposits in the Buntsandstein of the Krynica-Pasłęk region (see e.g., Miecznik et al., 2011; Solecki et al., 2011) and strongly positive gamma-ray anomalies within Buntsandstein sandstones and carbonates throughout the area (e.g., Szewczyk, 1987; Becker, 2019). Diagenetic illitization of smectite and kaolinite would destroy the primary ratios of clay minerals, but not the mineralogical composition of the bulk rock. Therefore, only the discussion about the distribution of illite, kaolinite and smectite should be treated with caution. The hypothetical diagenetic influence on the Bartoszyce succession may be less than assumed, since the illite content in kaolinite- and smectite-bearing Buntsandstein mudstones of southern Poland is comparable to or even higher than that reported here (Szamałek, 1989; Brański, 2007).

\section{BORON CONTENT}

A boron content in the range of 70 to $120 \mathrm{mg} / \mathrm{kg}$, as found in samples investigated, indicates contact with saline waters (Pasieczna, 1983; Środoń et al., 2014). This content fluctuates around the limit of $90 \mathrm{ppm}$ that differentiates between marine and non-marine sediments according to Pasieczna (1983). Środoń et al. (2014) concluded that increased concentrations of boron and other elements typical of saline waters can provide evidence of saline conditions during sedimentation if they positively correlate with the most fine-grained rocks with low permeability. No such correlation was observed in the section investigated. Therefore, diagenetic modification of the boron content cannot be excluded.

The inferred diagenetic illitization may also have influenced the boron content. The crystallization of illite involves first of all incorporation of potassium and other cations similar to potassium, including boron, substituting for silicon in the tetrahedral sheet (e.g., Perry, 1972; Środoń, 2010; Środoń et al., 2014). A higher amount of boron incorporated into the structure of silicate minerals in comparison to boron adsorbed on the surface of clay mineral particles can be expected within the upper part of the Malbork Formation. This can be assumed from the greatest difference in boron content between the results of the two digestion steps for the upper part of the Malbork Fm. (Fig. 9). Only a small amount of boron is incorporated into the crystalline structure of minerals within the Lidzbark Formation and the lower part of the Malbork Formation, with most boron being adsorbed on clay mineral surfaces. Also, smectite was detected in the upper part of the Malbork Formation, in contrast to the Lidzbark Formation and the lower part of the Malbork Formation, which, as opposed to the boron signal, indicates stronger illitization in the lower part of the succession. The boron content may have been altered by changes in detrital illite supply and sources (Perry, 1972). According to Perry (1972) recycled illite would retain the boron concentration inherited from its previous history.

Although boron content can be overprinted during diagenesis, it can still serve as a general accessory indicator of the depositional environment as suggested by Perry (1972). The results obtained here, though, do not allow any interpretation of depositional environment. The continental Keuper de- posits in southern Poland yielded boron contents of roughly the same range as those described here for the Middle Buntsandstein (Środoń et al., 2014). The distinction here between diagenetic and primary boron signals requires further research.

MICROFACIES, MINERALOGY AND GEOCHEMISTRY OF THE OOLITIC LIMESTONES - MARINE VS. TERRESTRIAL ORIGIN

Ooids building the oolitic limestones studied are mainly radial and such microstructure is considered to be primary in origin (see Flügel, 2004: 144). They are presently composed of low-Mg calcite, but originally they likely possessed high-Mg calcite mineralogy. The following observations support this inference: (1) well-preserved radial microstructure that was not destroyed during diagenesis, i.e. transformation of high-Mg calcite to low-Mg calcite, as would have been the case for aragonitic mineralogy, (2) relatively low content of $\mathrm{Sr}$ and high content of $\mathrm{Mg}$ (which excludes an originally aragonitic mineralogy), (3) the presence of small amounts of dolomite that could be related to release of Mg excess during calcite transformation (with subsequent precipitation of dolomite in a closed diagenetic system, as in the case of microdolomites - see e.g., Lohman and Meyers, 1977), 4) shells of gastropods and bivalves, that originally most probably were composed of aragonite, are completely leached and visible only due to synsedimentary cement or oolitic coatings.

The Early Triassic has been considered as an "aragonite sea" interval, when seawater chemistry favoured the precipitation of nonskeletal carbonates with aragonite and/or high-Mg calcite mineralogy (see Sandberg, 1983) which seems to stay in line with the observations on mineralogy above. However, the mineralogy of ooids precipitating in the seas of Permian-Triassic transitional time was variable. It changed from clearly aragonitic in the latest Permian to mixed (both aragonitic as well as high-Mg calcite, and in some cases also low-Mg calcite), which suggests unusual water chemistry during Early Triassic times (see discussion in Li et al., 2015).

Oolitic limestones from the Bartoszyce IG 1 borehole are similar to the Buntsandstein oolitic deposits known in other parts of the Triassic Central European Basin (see Kalkowsky, 1908; Usdowski, 1962; Weidlich, 2007; Paul et al., 2011). The equivalent oolites from Germany and western Poland were recently recognized as a product of short-lived marine transgressions from the Boreal realm or from the Tethys into the Central European Basin (see discussion in Weidlich, 2007 and in Szulc, 2019). As regards the common occurrence of untypically large ooids, the Buntsandstein oolitic limestones are comparable to more or less coeval Early Triassic oolites of the Tethys Ocean, widespread from Europe to China (see e.g., Tian et al., 2015; Li et al., 2019), that formed in the aftermath of the Permian-Triassic biotic crisis, when calcifying metazoans were lacking in the oceans. The Early Triassic oceans generally were characterized by a prevalence of unusual (so-called anachronistic) carbonate facies (such as oolites and microbialites) and the complete absence of skeletal deposits (see e.g., Woods, 2014). The Early Triassic Buntsandstein Basin with its untypical carbonates fits very well with this scenario.

The values of $\delta^{13} \mathrm{C}$ obtained from the oolitic limestones fit well with the ranges known for Lower Triassic marine carbonates (e.g., Veizer et al., 1999; Tanner, 2010; Algeo et al., 2011; Fig. 14), excluding the values of short-term positive excursions of this isotopic ratio (Horacek et al., 2007a). Almost all reported values of $\delta^{13} \mathrm{C}$ from Buntsandstein oolites from the Central European Basin show very narrow ranges between +1 and $-4 \%$ (Korte and Kozur, 2005; Becker, 2007; Weidlich, 2007; Scholze et al., 2017; Fig. 14). Again, narrow ranges of $\delta^{13} \mathrm{C}$ of $\sim 5 \%$ indi- 


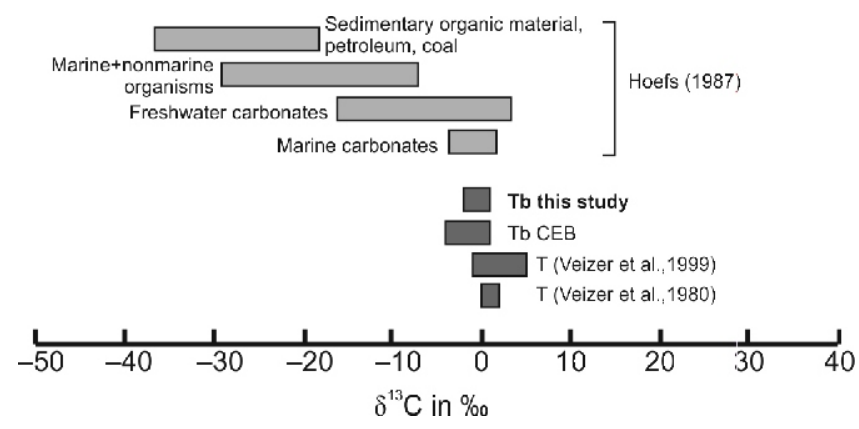

Fig. 14. $\delta^{13} \mathrm{C}$ results of this study, and other results from the Buntsandstein of the Central European Basin (CEB, Korte and Kozur, 2005; Becker, 2007; Scholze et al., 2017; this study), Triassic marine carbonates (Veizer et al., 1980) and Triassic marine fossils (Veizer et al., 1999) on the background of Hoefs (1987) interpretative model

$$
\mathrm{T} \text { - Triassic, Tb - Triassic, Buntsandstein }
$$

cate a marine rather than freshwater origin of the deposits (Hudson, 1977; Hoefs, 1987). The range of $\delta^{13} \mathrm{C}$ values in freshwater carbonates can reach $\sim 20 \%$ according to Hoefs (1987). However, in a lacustrine continental basin almost completely devoid of organic life (which means minor inputs of organic carbon dioxide) and with small amounts of carbon supplied from soil and bedrock dissolution (due to an extremely arid climate), one can expect equilibrium with atmospheric $\mathrm{CO}_{2}$. So, in such a scenario the $\delta^{13} \mathrm{C}$ of precipitated calcium carbonates should mirror shifts in carbon isotopic composition of the atmosphere and so be isotopically similar to marine carbonates. We note that the environment was heavily depleted in biogenic $\mathrm{CO}_{2}$ due to the extinction at the Permian-Triassic boundary and the low level of recovery during the Early Triassic (e.g., Wignall and Hallam, 1992; Algeo et al., 2007; Wignall, 2007; Song et al, 2018). Nevertheless, greater fluctuations can be expected in continental environments.

Numerous studies have shown that very stressful environmental conditions leading to repeated biotic crises persisted through all of the Early Triassic (e.g., Algeo et al., 2007, 2011). Rare bioclasts found within the oolitic limestones examined indicate a faunal assemblage of relatively low numbers and diversity, which could be expected during the Early Triassic either in the sea or in a continental playa lake (e.g., Weidlich, 2007). A continental playa lake environment, though, is stressful without any additional external influence (e.g., De Deckker, 1983; Haukos and Smith, 1992).

The very variable microfabrics and diameters of individual ooids suggest rapid changes in wave/current energy and water chemistry over short periods of time, as Weidlich (2007) concluded. Such unstable conditions can be expected in ooidal shoals or bars that formed in a very shallow environment and that appeared episodically. High depositional energy and repeated reworking is demonstrated by erosional surfaces and intraclasts.

Another question here is the cause of the clear depletion trend of $\delta^{13} \mathrm{C}$ to the top of the oolite-bearing part of the section. Quasi-cyclic fluctuations of carbonate $\delta^{13} \mathrm{C}$ during the Early Triassic are reported from successions from all over the world (Algeo et al., 2007, 2011; Horacek et al., 2007a, b; Tanner, 2010; Fig. 15). Algeo et al. (2007) attributed this to repeated episodes of upwelling of deep waters with ${ }^{13} \mathrm{C}$-deficiency, while Horacek et al. (2007a) related it to circulation periods of oceanic waters, which cause a mixture of relatively bio-productive sur-

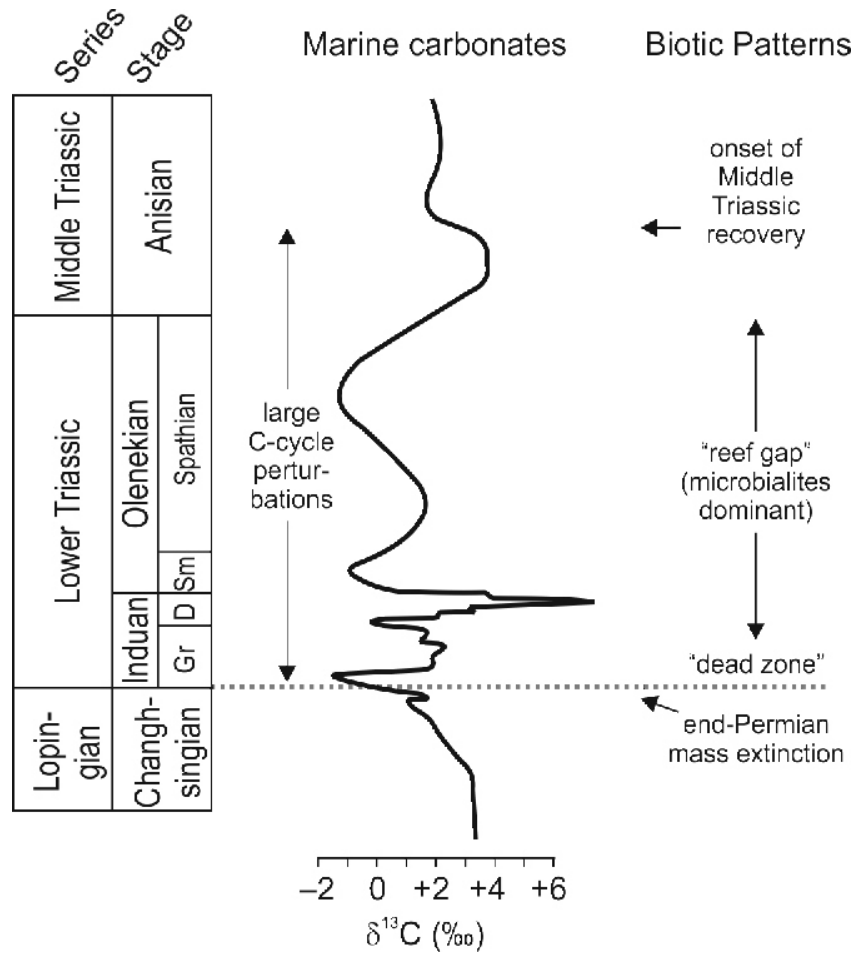

Fig. 15. Large $\mathrm{C}$-cycle perturbations and biotic patterns in Permian-Triassic oceans, from Algeo et al. (2007, 2011, with references therein, modified)

Gr - Griesbachian, D - Dienerian, Sm - Smithian

face waters with anoxic deep waters. The observed decline of $\delta^{13} \mathrm{C}$ may reflect a changing chemistry of the seawater caused by one of these episodes, and may also indicate a permanent connection to the open ocean.

Another explanation could be the changes in facies upwards in the section examined. The oolitic limestones investigated are interpreted as having formed in shoals or bars separating a very shallow lagoon. The limestones are overlain by the lagoonal deposits. The entire section represents a sustained environmental shallowing-upwards trend as characterized earlier and supported by palynofacies analysis. The shallowing may have been accompanied by increasing fresh water supply from the mainland and a decrease in salinity. As described by Shao et al. (2000) for marine deposits or by Środoń et al. (2014) for continental deposits, a reduction in salinity coincides with decrease in carbon isotope values. The observed decrease in $\delta^{13} \mathrm{C}$ values could therefore reflect a local environmental change and not necessarily a global oceanic geochemical episode.

\section{CONCLUSIONS}

The Middle Buntsandstein succession examined was deposited in two main environmental domains: (1) a permanent or almost permanent, very shallow aqueous basin with ooidal shoals/bars and margins, formed by weakly developed barriers and lagoons or deltas, and (2) an alluvial plain. The boundary between the two domains lies within the Malbork Formation, dividing it into a lower and an upper part. Remarkably, all the important mineralogical and geochemical changes reported coincide more or less with this boundary, although it is not very pronounced lithologically (Fig. 16). This brings two conclusions: (1) 


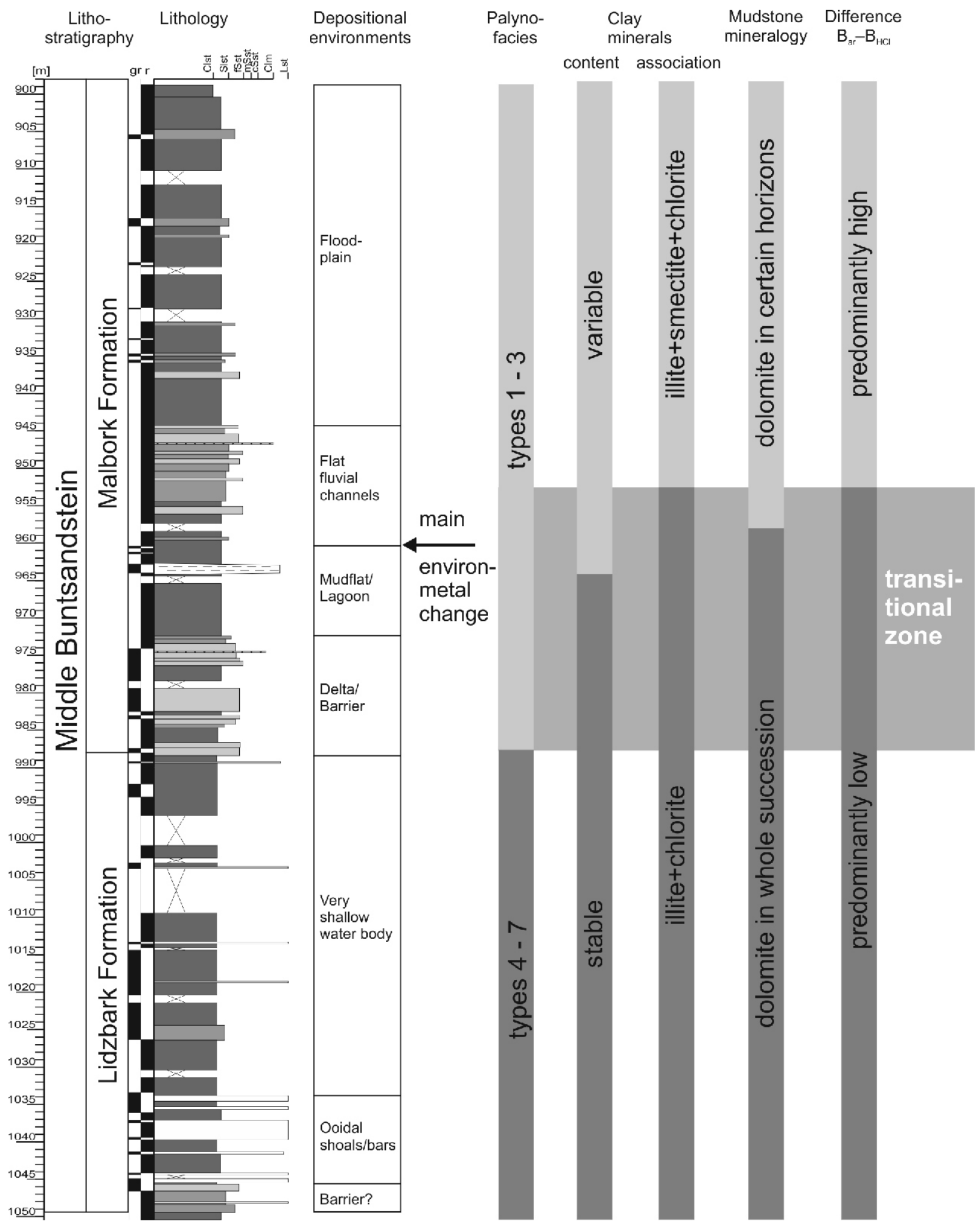

Fig. 16. Main geological and geochemical patterns of the Middle Buntsandstein of the Bartoszyce IG 1 borehole

$\mathrm{B}_{\mathrm{ar}}$ - boron content measured after aqua regia treatment, $\mathrm{B}_{\mathrm{HCl}}-$ boron content measured after $\mathrm{HCl}$ treatment; explanations as on Figure 4 
the change in the depositional environment had to be more significant than a change between two continental systems fed by waters with more or less the same geochemistry, (2) the hypothesized diagenetic overprint did not completely destroy the primary environmental signal.

The regional differentiation of the clay mineral assemblage in the Polish part of the Buntsandstein basin, which shows kaolinite depletion towards the north, suggests that the basin was controlled by a connection with an open marine realm (if any) to the north, rather than to the south. The marine condition of deposition inferred could not be demonstrated unequivocally. The clay mineralogy as well as boron content may have been affected by diagenetic illitization caused by a hydrothermal event.

The palynofacies analysis suggests that the lower part of the Lidzbark Formation was deposited in a marine basin, documented by the presence of "fluffy" AOM, while its upper part was deposited in a brackish lagoon. The upper part of the Malbork Formation originated on a floodplain. The uniformity of the mineralogical composition of the fine-grained sediments of the Lidzbark Formation and lowermost part of the Malbork Formation strengthens this interpretation as well as the values and narrow $\delta^{13} \mathrm{C}$ ranges of the oolitic limestones. Nevertheless, neither acritarchs nor prasinophytes were found in the palynofacies investigated, which are the most significant marine palynofacies indicators.

The ooids investigated were probably primarily composed of high-Mg calcite and are closely comparable with those of Early Triassic deposits of the Tethys Ocean.

The observed $\delta^{13} \mathrm{C}$ depletion in the oolite-bearing part of the section may reflect a local environmental change associated with salinity reduction and not necessarily one of a global oceanic geochemical episode, though the latter cannot be excluded. It would also indicate a permanent link with the open ocean.
We cannot resolve unequivocally the question of marine origin of the Middle Buntsandstein deposits in north-eastern Poland. But, we outline the complexity of the problem, applicable across the whole Central European Basin, and provide constraints on previous interpretations. The lack of typical marine features of deposits of this basin need to be discussed in a broad global context of the specifically extraordinary times of the aftermath of the largest environmental crisis in Earth history. The Early Triassic oceans generally were characterized by anachronistic carbonate facies and the absence of skeletal deposits. The lack of unequivocal arguments for a purely continental origin of the Buntsandstein deposits of the Central European Basin raises doubts on predominantly climatic and orbital control on its deposition. There is a need for further multidisciplinary research on the Buntsandstein in the different parts of the Central European Basin to achieve a reliable reconstruction of its complex depositional system, that avoids oversimplified conclusions.

Acknowledgements. Study of the Bartoszyce IG 1 borehole was financed by the National Fund for Environmental Protection and Water Management within the scope of the project "Zabezpieczenie stratotypowych odcinków rdzeni wiertniczych, etap II: dodatkowe badania na rdzeniach oraz prace logistyczno-techniczne w archiwach rdzeni" No. 22.9012.1201.00.0 to the Polish Geological Institute. We thank W. Narkiewicz for providing XRD analyses and J. Kucharzyk, I. Jaroń and W. Bureć-Drewniak for providing ICP-OES analyses as well as D. Lech for fruitful discussion. Prof. M. Kowal-Linka and Dr. H.-G. Röhling are greatly acknowledged for their insightful reviews, valuable critical remarks and suggested corrections, which considerably helped to improve the manuscript. The final editorial work was supported by the PGI-NRI statutory funds (Project No. 62.9012.1932.00.0).

\section{REFERENCES}

Algeo, T.J., Brooks, E., Nguyen, T.K.T., Rowe, H., Maynard, J.B., 2007. The Permian-Triassic boundary at Nhi Tao, Vietnam: evidence for recurrent influx of sulfidic watermasses to a shallow-marine carbonate platform. Palaeogeography, Palaeoclimatology, Palaeoecology, 252: 304-327.

Algeo, T.J., Chen, Z.Q., Fraiser, M.L., Twitchett, R.J., 2011. Terrestrial-marine teleconnections in the collapse and rebuilding of Early Triassic marine ecosystems. Palaeogeography, Palaeoclimatology, Palaeoecology, 308: 1-11.

Amsterdam Palynological Organic Matter Classification, Lumcon, Cocodrie, Oct. $29^{\text {th }}-$ Nov. $1^{\text {st }}, 1993$, Materials of workshop.

Bachmann, G.H., Geluk, M.C., Warrington, G., Becker-Roman, A., Beutler, G., Hagdorn, H., Hounslow, M.W., Nitsch, E., Röhling, H.-G., Simon, T., Szulc, A., 2010. Triassic. In: Petroleum Geological Atlas of the Southern Permian Basin Area (eds. J.C. Doornenbal and A.G. Stevenson): 149-173. EAGE Publications b.v. (Houten)

Batten, D.J., 1996. Palynofacies and palaeoenvironmental interpretations. American Association of Stratigraphic Palynologists Foundation, 3: 1011-1064.

Becker, A., 2005. Sequenzstratigraphie und Fazies des Unteren und Mittleren Buntsandsteins im östlichen Teil des Germanischen Beckens (Deutschland, Polen). Hallesches Jahrbuch für Geowissenschaften, Reihe B, Beiheft, 21: 1-117.
Becker, A., 2007. Marine environment in the Lower and Middle Buntsandstein of the Central European Basin - summary of the facts. Schriftenreihe der Deutschen Geologischen Gesellschaft, 53: 54-55.

Becker, A., 2014. Facje i cykliczność sedymentacji dolnego i środkowego pstrego piaskowca (in Polish). Profile Głębokich Otworów Wiertniczych Państwowego Instytutu Geologicznego, 141: $155-164$

Becker, A., 2019. Trias. Stratygrafia, litologia i zarys przebiegu sedymentacji pstrego piaskowca (in Polish). Profile Głębokich Otworów Wiertniczych Państwowego Instytutu Geologicznego, 154: 110-111.

Becker, A., Kuleta, M. Narkiewicz, K., Pieńkowski, G., Szulc, J., 2008. Trias (in Polish). In: Tabela stratygraficzna Polski. Polska pozakarpacka (ed. R. Wagner). Państwowy Instytut Geologiczny, Warszawa

Becker, A., Fijałkowska-Mader, A., Nawrocki, J., Sobień, K., 2020. Integrated palynostratigraphy and magnetostratigraphy of the Middle and Upper Buntsandstein in NE Poland - an approach for correlation of the Lower Triassic regional isochronous horizons. Geological Quarterly, 64 (2): 460-479.

Bergen v., P.F., Kerp, J.H.P., 1990. Palynofacies and sedimentary environments of a Triassic section in Southern Germany. Mededelingen Rijks Geologische Dienst, 45: 24-31. 
Beutler, G., Szulc, J., 1999. Die paläogeographische Entwicklung des Germanischen Beckens in der Trias und die Verbindung zur Tethys. In: Trias - Eine ganz andere Welt (eds. N. Hauschke and V. Wilde): 71-80. Pfeil Verlag, München.

Boulter, M.C., Riddick, A., 1986. Classification and analysis of palynodebris from the Palaeocene sedments of the Forties Field. Sedimentology, 33: 871-886.

Brański, P., 2007. An estimate of possible use of selected pre-Cenozoic clays from Poland for environmental protection (in Polish with English summary). Przegląd Geologiczny, 55: 467-474.

Brański, P., 2012. The mineralogical record of the Early Toarcian stepwise climate changes and other environmental variations (Ciechocinek Formation, Polish Basin). Volumina Jurassica, 10 1-24.

Brański, P., 2014. Climatic disaster at the Triassic-Jurassic boundary - a clay minerals and major elements record from the Polish Basin. Geological Quarterly, 58 (2): 291-310.

Briere, P.R., 2000. Playa, playa lake, sabkha: Proposed definitions for old terms. Journal of Arid Environments, 45: 1-7.

Chamley, H., 1989. Clay Sedimentology. Springer, Berlin, Heidelberg.

Czapowski, G., Fijałkowska, A., Gąsiewicz, A., Krystkiewicz, E., Langier-Kuźniarowa, A., Nawrocki, J., 1994. Granica perm-trias w południowo-zachodniej Polsce, temat nr 2.13.0309.00.0 (in Polish). Narodowe Archiwum Geologiczne, nr inw. 563/94.

De Deckker, P., 1983. Australian salt lakes: their history, chemistry, and biota - a review. Hydrobiologia, 105: 231-244.

Driese, S.G., Mora, C.I., Stiles, C.A., Joeckel, R.M., Nordt, L.C., 2000. Mass-balance reconstruction of a modern Vertisol: implications for interpreting the geochemistry and burial alteration of paleo-Vertisols. Geoderma, 95: 179-204

Dyrka, I., 2014. Analiza tempa depozycji oraz modelowanie historii termicznej i warunków pogrzebania (in Polish). Profile Głębokich Otworów Wiertniczych Państwowego Instytutu Geologicznego, 138: 161-164.

Feldman-Olszewska, A., 2014. Charakterystyka litologicznostratygraficzna utworów dolnego i środkowego pstrego piaskowca oraz stratygrafia sekwencji (in Polish). Profile Głębokich Otworów Wiertniczych Państwowego Instytutu Geologicznego, 141: 141-154.

Fijałkowska, A., 1994. Palynostratigraphy of the Lower and Middle Buntsandstein in NW part of the Holy Cross Mountains, Poland Geological Quarterly, 38 (1): 59-96.

Fijałkowska, A., 1995. Palynostratigraphy and palynofacies of the Permian/Triassic sequence in the Żary Pericline (SW Poland). Geological Quarterly, 39 (3): 307-324.

Fijałkowska-Mader, A., 1999. Palynostratigraphy, palaeoecology and palaeoclimatology of the Triassc in South-Eastern Poland Zentralblatt für Geologie und Paläontologie. Teil I, 1998 (7-8): 601-627.

Fijałkowska-Mader, A., 2015. A record of climatic changes in the Triassic palynological spectra from Poland. Geological Quarterly, 59 (4): 615-653.

Fijałkowska-Mader, A., Heunisch, C., Szulc, J., 2015a Palynostratigraphy and palynofacies of the Upper Silesian Keuper (Southern Poland). Annales Societatis Geologorum Poloniae, 85 637-661.

Fijałkowska-Mader, A., Kuleta, M., Zbroja S., 2015 b. Lithostratigraphy, palynofacies and depositional environments of the Triassic deposits in the northern part of the Nida Basin (in Polish with English summary). Biuletyn Państwowego Instytutu Geologicznego, 462: 83-124

Flügel, E., 2004. Microfacies of Carbonate Rocks: Analysis, Interpretation and Application. Springer, Berlin, Heidelberg.

Fuglewicz, R., 1973. Megaspores of Polish Buntersandstein and their stratigraphical significance. Acta Palaeontologica Polonica, 18: 401-453.

Fuglewicz, R., 1980. Stratigraphy and palaeogeography of Lower Triassic in Poland on the basis of megaspores. Acta Geologica Polonica, 30: 417-470.
Haukos, D.A., Smith, L.M., 1992. 13.3.7. Ecology of Playa Lakes Waterfowl Management Handbook, 19: 1-7.

Heunisch, C., Röhling, H.-G., 2016. Early Triassic phytoplankton episodes in the Lower and Middle Buntsandstein of the Central European Basin. Zeitschrift der Deutschen Gesselschaft für Geowissenschaften, 167: 227-248.

Heunisch, C., Luppold, F.W., Reinhardt, L., Röhling, H.-G., 2010. Palynofazies, Bio- und Lithostratihgraphie im Grenzebereich Trias/Jura in der Bohrung Mariental 1 (Lappwaldmulde, Ostniedersachsen). Zeitschrift der Deutschen Gesellschaft für Geowissenschaften, 161: 51-98.

Hoefs, J., 1987. Stable isotope geochemistry. Third, completely revised and enlarged edition. Minerals and rocks, 9. Springer.

Horacek, M., Brandner, R., Abart, R., 2007a. Carbon isotope record of the P/T boundary and the Lower Triassic in the Southern Alps: Evidence for rapid changes in storage of organic carbon. Palaeogeography, Palaeoclimatology, Palaeoecology, 252: 347-354.

Horacek, M., Richoz, S., Brandner, R., Krystyn, L., Spötl, C., 2007b. Evidence for recurrent changes in Lower Triassic oceanic circulation of the Tethys: The $\delta^{13} \mathrm{C}$ record from marine sections in Iran. Palaeogeography, Palaeoclimatology, Palaeoecology, 252: 355-369

Hounslow, M., Muttoni, G., 2010. The geomagnetic polarity timescale for the Triassic: linkage to stage boundary definitions Geological Society Special Publications, 334: 61-102.

Hudson, J.D., 1977. Stable isotopes and limestone lithification. Journal of the Geological Society, 133: 637-660.

Iwanow, A., Kiersnowski, H., 1998. Plate 12 Middle Bunter, older part palaeogeography. Plate 13 Middle Bunter, younger part palaeogeography (in Polish with English summary). In: Palaeogeographical atlas of the epicontinental Permian and Mesozoic in Poland (eds. R. Dadlez, S. Marek and J. Pokorski). Wydawnictwo Kartograficzne Polskiej Agencji Ekologicznej, Warszawa.

Jewuła, K., Matysik, M., Paszkowski, M., Szulc, J., 2019. The late Triassic development of playa, gilgai floodplain, and fluvial environments from Upper Silesia, southern Poland. Sedimentary Geology, 379: 25-45.

Kalkowsky, E., 1908. Oolith und Stromatolith im norddeutschen Buntsandstein. Zeitschrift der Deutschen Geologischen Gesselschaft, 60: 68-125.

Korte, Ch., Kozur, H.W., 2005. Carbon isotope trends in continental lake deposits of uppermost Permian to Lower Olenekian Germanic Lower Buntsandstein (Calvörde and Bernburg Formations). Hallesches Jahrbuch für Geowissenschaften B, 19: 87-94

Kutzbach, J.E., Gallimore, R.G., 1989. Pangaean climate: megamonsoons of the megacontinent. Journal of Geophysical Research, 94D: 3341-3357.

Last, W.M., 1984. Sedimentology of playa lakes of the northern Great Plains. Canadian Journal of Earth Sciences, 21 107-125.

Li, F., Yan, J., Chen, Z.-Q., Ogg, J.G., Tian, L., Korngreen, D., Liu, K., Ma, Z., Woods, A.D., 2015. Global oolite deposits across the Permian-Triassic boundary: a synthesis and implications for palaeoceanography immediately after the end-Permian biocrisis. Earth-Science Reviews, 149: 163-180

Li, F., Gong, Q., Burne, R.V., Tang, H., Su, C., Zeng, K., Zhang, Y., Tan, X., 2019. Ooid factories operating under hothouse conditions in the earliest Triassic of South China. Global and Planetary Change, 172: 336-354.

Lohmann, K.C., Meyers, W.J., 1977. Microdolomite inclusions in cloudy prismatic calcites; a proposed criterion for former high-magnesium calcites. Journal of Sedimentary Research, 47: 1078-1088

Marcinkiewicz, T., 1992. Megaspore stratigraphical scheme of the Buntsandstein sediments in Poland (in Polish with English summary). Biuletyn Państwowego Instytutu Geologicznego, 368: 65-96.

Marcinkiewicz, T., Fijałkowska-Mader, A., Pieńkowski, G., 2014. Megaspore zones of the epicontinental Triassic and Jurassic 
deposits in Poland - overview (in Polish with English summary). Biuletyn Państwowego Instytutu Geologicznego, 457: 15-42.

Miecznik, J.B., Strzelecki, R., Wołkowicz, S., 2011. Uranium in Poland - history of prospecting and chances for finding new deposits (in Polish with English summary). Przegląd Geologiczny, 59: 688-697.

Nawrocki, J., 1997. Permian to Early Triassic magnetostratigraphy from the Central European Basin in Poland: Implications on regional and worldwide correlations. Earth and Planetary Science Letters, 152: 37-58.

Nowak, H., Schneebeli-Herman, E., Kustascher, E., 2018. Correlation of Lopingian to Middle Triassic Palynozones. Journal of Earth Science, 29: 755-777.

Nowicka, M., 1974a. Wyniki badań petrograficznych. Trias. Piaskowiec pstry (in Polish). Profile Głębokich Otworów Wiertniczych Instytutu Geologicznego, 14: 268-282.

Nowicka, M., 1974b. Pokrywa mezozoiczna. Trias. Trias dolny (in Polish). Prace Instytutu Geologicznego, 74: 122-135.

Odin, G.S., Matter, A., 1981. De glaukoniarum origine. Sedimentology, 28: 611-641.

Orłowska-Zwolińska, T., 1977. Palynological correlation of the Bunter and Muschelkalk in selected profiles from Western Poland. Acta Geologica Polonica, 27: 417-430.

Orłowska-Zwolińska, T., 1983. Palynostratigraphy of the upper part of Triassic epicontinental sediments in Poland (in Polish with English summary). Prace Instytutu Geologicznego, 104: 1-89.

Orłowska-Zwolińska, T., 1984. Palynostratigraphy of the Buntsandstein in section of Western Poland. Acta Palaeontologica Polonica, 29: 161-194.

Orłowska-Zwolińska, T., 1985. Palynological zones of the Polish epicontinental Triassic. Bulletin of Polish Academy of Sciences, Earth Sciences, 33: 107-119.

Palermo, D., Aigner, T., Geluk, M., Poeppelreiter, M., Pipping, K., 2008. Reservoir potential of a lacustrine mixed carbonate/siliciclastic gas reservoir: the Lower Triassic Rogenstein in the Netherlands. Journal of Petroleum Geology, 31: 61-96.

Parrish, J.T., 1993. Climate of the Supercontinent Pangea. Journal of Geology, 101: 215-233.

Pasieczna, A., 1983. Geochemistry of boron in the Carboniferous sediments of the Mazowsze-Lublin Trough (eastern Poland) (in Polish with English summary). Archiwum Mineralogiczne, 38: 77-143.

Paul, J., 1982. Der Untere Buntsandstein des germanischen Beckens. Geologische Rundschau, 71: 795-811.

Paul, J., 1999a. Fazies und Sedimentstrukturen des Buntsandsteins. In: Trias - Eine ganz andere Welt (eds. N. Hauschke and V. Wilde): 105-114. Pfeil Verlag, München.

Paul, J., 1999b. Oolithe und Stromatolithen im Unteren Buntsandstein. In: Trias - Eine ganz andere Welt (eds. N Hauschke and V. Wilde): 263-270. Pfeil Verlag, München.

Paul, J., Peryt, T.M., 2000. Kalkowsky's stromatolites revisited (Lower Triassic Buntsandstein, Harz Mountains, Germany). Palaeogeography, Palaeoclimatology, Palaeoecology, 161: 435-458.

Paul, J., Peryt, T.M., Burne, R.V., 2011. Kalkowsky's stromatolites and oolites (Lower Buntsandstein, Northern Germany). Lecture Notes in Earth Sciences, 131: 13-28.

Perry, E.D., 1972. Diagenesis and the validity of the boron paleosalinity technique. American Journal of Science, 272 150-160.

Peryt, T.M., 1975. Significance of stromatolites for the environmental interpretation of the Buntsandstein (Lower Triassic) rocks. Geologische Rundschau, 64: 143-158.

Pieńkowski, G., 1991. Facies criteria for delimitating Zechstein/Buntsandstein and Permian/Triassic boundaries in Poland. Zentralblatt für Geologie und Paläontologie, 1991: 893-912.

Pieńkowski, G., Waksmundzka, M., 2009. Palynofacies in Lower Jurassic epicontinental deposits of Poland: tool to interpret sedimentary environments. Episodes, 32: 21-32.

Powell, A.J., Dodge, J.D., Lewis, J., 1990. Late Neogene to Pleistocene palynological facies of the Peruvian continental margin upwelling, Leg 112. Proceedings of the Ocean Drilling Project, Scientific Results, 112: 297-321.

Rahimpour-Bonab, H., Abdi, L., 2012. Sedimentology and origin of Meyghan lake/playa deposits in Sanandaj-Sirjan zone, Iran. Carbonates and Evaporites, 27: 375-393.

Reitz, E., 1985. Palynologie der Trias in Nordhessen und Südniedersachsen. Geologische Abhandlungen Hessen, 86: 1-36.

Riding, H.G. (ed.), 1996. Sedimentary Environments: Processes, Facies and Stratigraphy - 3rd ed. Blackwell Science, Oxford.

Sandberg, P.A., 1983. An oscillating trend in Phanerozoic non-skeletal carbonate mineralogy. Nature, 305: 19-22.

Scholze, F., Wang, X., Kirchner, U., Kraft, J., Schneider, J.W., Götz, A.E., Joachimski, M.M., Bachtadse, V., 2017. A multistratigraphic approach to pinpoint the Permian-Triassic boundary in continental deposits: The Zechstein-Lower Buntsandstein transition in Germany. Global and Planetary Change, 152: 129-151.

Senkowiczowa, H., 1997. Trias dolny (pstry piaskowiec) Biostratygrafia (in Polish). Prace Państwowego Instytutu Geologicznego, 153: 84-111.

Shao, L., Zhang, P., Dou, J., Shen, S., 2000. Carbon isotope composition of the Late Permian carbonate rocks in southern China: their variations between the Wujiaping and Changxing formations. Palaeogeography, Palaeoclimatology, Palaeoecology, 161: $179-192$

Sheldon, N.D., Tabor, N.J., 2009. Quantitative paleoenvironmental and paleoclimatic reconstruction using paleosols. Earth-Science Reviews, 95: 1-52.

Schön, M., 1967. Hystrichosphaerideen aus dem Mittleren Buntsandstein von Thüringen. Monatsberichte der Deutschen Akademie der Wissenschaften zu Berlin, 9: 527-535.

Schütt, B., 2004. The chemistry of playa-lake-sediments as a tool for the reconstruction of Holocene environmental conditions - a case study from the central Ebro basin. Lecture Notes in Earth Sciences, 102: 5-30.

Solecki, A., Śliwiński, W., Wojciechowska, I., Tchorz-Trzeciakiewicz, D., Syryczyński, P., Sadowska, M., Makowski, B., 2011. Ocena możliwości występowania mineralizacji uranowej w Polsce na podstawie wyników prac geologiczno-poszukiwawczych (in Polish). Przegląd Geologiczny, 59: 98-110.

Song, H., Wignall, P.B., Dunhill, M.A., 2018. Decoupled taxonomic and ecological recoveries from the Permo-Triassic extinction. Science Advances, 2018 (4): eaat5091, 1-6.

Stolarczyk, F., 1972. New data on the Permian deposits in the eastern part of the Peri-Baltic Syneclise (in Polish with English summary). Kwartalnik Geologiczny, 16 (1): 113-130.

Styk, O., 1974. Wyniki badań mikrofaunistycznych piaskowca pstrego (in Polish). Profile Głębokich Otworów Wiertniczych Instytutu Geologicznego, 14: 155-157.

Szamałek, K., 1989. Lithology versus raw material properties of the Lower Triassic clay rocks in the north-western margin of the Góry Świętokrzyskie (in Polish with English summary). Biuletyn Państwowego Instytutu Geologicznego, 361: 55-106.

Szewczyk, J., 1987. Possibility of geophysical forecast of the uranium mineralization zones in the Triassic formations in the Peribaltic Syneclise area (in Polish with English summary). Przegląd Geologiczny, 35: 394-402.

Szuflicki, M., Malon, A., Tymiński, M. (eds.), 2019. Bilans zasobów złóż kopalin w Polsce (wg stanu na 31.XII.2018 r.) (in Polish). Państwowy Instytut Geologiczny-Państwowy Instytut Badawczy, Warszawa.

Szulc, J., 2019. Lower Triassic marine Buntsandstein deposits in the Central European Basin. Zeitschrift der Deutschen Gesellschaft für Geowissenschaften, 170: 311-320.

Szulc, J., Becker, A., Fijałkowska-Mader, A., 2015. Perm i trias nowe otwarcie w historii Gór Świętokrzyskich (in Polish). In: Ekstensja i inwersja powaryscyjskich basenów sedymentacyjnych. 85 Zjazd Polskiego Towarzystwa Geologicznego, Chęciny, 9-11 września 2015 r. (eds. S. Skompski and W. Mizerski): 11-27. Państwowy Instytut GeologicznyPaństwowy Instytut Badawczy, Warszawa. 
Szyperko-Śliwczyńska, A., 1974. Szczegółowy profil litologiczno-stratygraficzny otworu wiertniczego Bartoszyce IG 1. Trias. Piaskowiec pstry (in Polish). Profile Głębokich Otworów Wiertnicznych Instytutu Geologicznego, 14: 37-48.

Szyperko-Śliwczyńska, A., 1979. Lower Trias in north-eastern Poland (in Polish with English summary). Prace Instytutu Geologicznego, 91: 1-77.

Szyperko-Teller, A., 1997a. Trias dolny (pstry piaskowiec) Formalne i nieformalne jednostki litostratygraficzne (in Polish). Prace Państwowego Instytutu Geologicznego, 153: 112-117.

Szyperko-Teller, A., 1997b. Trias dolny (pstry piaskowiec). Sedymentacja, paleogeografia i paleotektonika (in Polish). Prace Państwowego Instytutu Geologicznego, 153: 121-132.

Szyperko-Teller, A., Moryc, W., 1988. Evolution of the Buntsandstein sedimentary basin in Poland (in Polish with English summary). Kwartalnik Geologiczny, 32 (1): 53-72.

Środoń, J., 2010. Evolution of boron and nitrogen content during illitization of bentonites. Clays and Clay Minerals, 58: 743-756.

Środoń, J., Szulc, J., Anczkiewicz, A., Jewuła, K., Banaś, M., Marynowski, L., 2014. Weathering, sedimentary and diagenetic controls of mineral and geochemical characteristics of the vertebrate-bearing Silesian Keuper. Clay Minerals, 49 569-594.

Talbot, M.R., Allen, P.A., 1996. Lakes. In: Sedimentary Environments: Processes, Facies and Stratigraphy (ed. H.G. Reading) 83-124. Blackwell Science, Oxford.

Tanner, L.H., 2010. The Triassic isotope record. Geological Society Special Publications, 334: 103-118.

Thamban, M., Rao, V.P., Schneider, R.R., 2002. Reconstruction of late Quaternary monsoon oscillations based on clay mineral proxies using sediment cores from the western margin of India. Marine Geology, 186: 527-539.

Tian, L., Bottjer, D.J., Tong, J., Li, F., Yang, T., Song, Haijun, Song, Huyue, Liang, L., 2015. Distribution and size variation of ooids in the aftermath of the Permian-Triassic mass extinction Early Triassic ooids. Palaios, 30: 714-727.

Tyson, R.V., 1993. Palynofacies analysis. In: Applied Micropaleontology (ed. D.G. Jenkins): 153-191. Kluwer Academic Publishers, Netherlands.
Tyson, R.V., 1995. Sedimentary Organic Matter. Chapman et Hall, London, New York, Tokyo.

Usdowski, D.H.-E., 1962. Die Entstehung der kalkoolithischen Fazies des norddeutschen Unteren Buntsandsteins. Beiträge zur Mineralogie und Petrographie, 8: 141-179.

Van der Zwan, C.J., Spaak, P., 1992. Lower to Middle Triassic sequence stratigraphy and climatology of the Netherlands, a model. Palaeogeography, Palaeoclimatology, Palaeoecology, 91: 277-290.

Veizer, J., Holser, W.T., Wilgus, C.K., 1980. Correlation of ${ }^{13} \mathrm{C} /{ }^{12} \mathrm{C}$ and ${ }^{34} \mathrm{~S} /{ }^{32} \mathrm{~S}$ secular variations. Geochimica et Cosmochimica Acta, 44: 579-587.

Veizer, J., Ala, D., Azmy, K. Bruckschen, P., Buhl, D., Bruhn, F., Carden, G.A.F., Diener, A., Ebneth, S., Godderis, Y., Jasper, T., Korte, C., Pawellek, F., Podlaha, O.G., Strauss, H., 1999. ${ }^{87} \mathrm{Sr} /{ }^{86} \mathrm{Sr}, \delta^{13} \mathrm{C}$ and $\delta^{18} \mathrm{O}$ evolution of Phanerozoic seawater. Chemical Geology, 161: 59-88.

Voigt, T., Gaupp, R., 2000. Die fazielle Entwicklung an der Grenze zwischen Unterem und Mittlerem Buntsandstein im Zentrum der Thüringer Senke. Beitrage zur Geologie von Thüringen, Neue Folge, 7: 55-71.

Weidlich, O., 2007. PTB mass extinction and earliest Triassic recovery overlooked? New evidence for a marine origin of Lower Triassic mixed carbonate-siliciclastic sediments (Rogenstein Member), Germany. Palaeogeography, Palaeoclimatology, Palaeoecology, 252: 259-269.

Wignall, P.B., 2007. The end-Permian mass extinction - how bad did it get? Geobiology, 5: 303-309.

Wignall, P.B., Hallam, A., 1992. Anoxia as a cause of the Permian/Triassic mass extinction: facies evidence from northern Italy and the western United States. Palaeogeography, Palaeoclimatology, Palaeoecology, 93: 21-46.

Woods, A.D., 2014. Assessing Early Triassic paleoceanographic conditions via unusual sedimentary fabrics and features. Earth-Science Reviews, 137: 6-18.

Ziegler, P. A., 1990. Geological Atlas of Western and Central Europe (2nd edition). Shell Internationale Petroleum Maatschappij B. V., Geological Society Publishing House (Bath), Den Haag. 